\title{
THE EFFECTS OF NEW MEDIA FOR EMERGENCY TORNADO NOTIFICATION ON THE DIGITAL DIVIDE
}

\author{
A Thesis presented to the Faculty of the Graduate School \\ University of Missouri - Columbia \\ In Partial Fulfillment \\ Of the Requirements for the Degree \\ Master of Arts \\ By \\ STEPHANIE MEYERS
}

Dr. Esther Thorson, Thesis Supervisor

MAY 2014 
The undersigned, appointed by the dean of the Graduate School, have examined the thesis entitled

\section{THE EFFECTS OF NEW MEDIA FOR EMERGENCY TORNADO NOTIFICATION ON THE DIGITAL DIVIDE}

presented by Stephanie Meyers, a candidate for the degree of master of journalism, and hereby certify that, in their opinion, it is worthy of acceptance.

Dr. Esther Thorson

Dr. Glenn Leshner

Dr. María Len-Ríos

Dr. Brian Houston 


\section{ACKNOWLEDGEMENTS}

I would like to thank my thesis committee members who guided me through this intricate process: Dr. Esther Thorson, Dr. Glenn Leshner, Dr. María Len-Ríos and Dr. Brian Houston. They provided not only their time, but also their unique research experience, skill and expertise to maximize this research project to make an impact for future researchers on this topic.

Special thank you to Dr. Thorson for being my committee chair and helping me through the most difficult phases of this process. Dr. Houston provided reassurance and direction when needed, and his unique experience with research in disaster communication was helpful when creating the survey questions and what analysis would be best suited for the data collected.

I would also like to thank Sarah Smith-Frigerio, who kept me on track, answered possibly hundreds of my questions and made herself ever available. My deepest gratitude to my employer, Emergency Communications Network (ECN), and a few key ECN staff including Jim Haddox, Production Manager, Alan Epstein, VP Operations and David DiGiacomo, President for not only allowing me to use company resources to execute this project, but also for their unwavering support. 
The research study would not have been possible without the support of Cindi Lane, Communications \& Marketing Manager for the City of Palm Coast, FL, and Chana Lyn Ray, Administrative Assistant for the Douglas County Emergency Management Agency in Illinois. Both women provided tireless support and made themselves available throughout the process. I am forever grateful for Cindi and Chana. 


\section{TABLE OF CONTENTS}

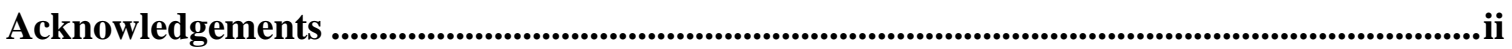

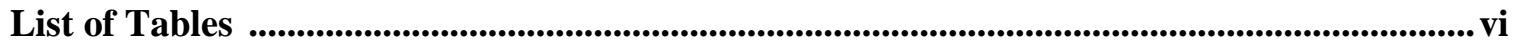

Abstract................................................................................................................................................................viii

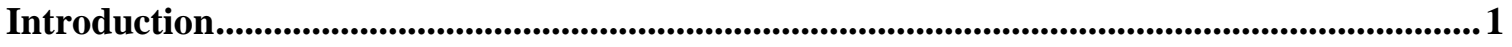

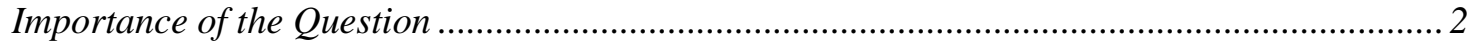

Question Importance to Field of Journalism \& Mass Communication .......................................4

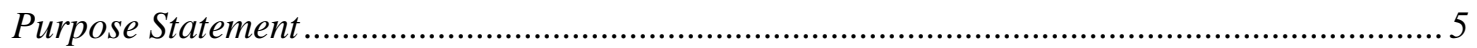

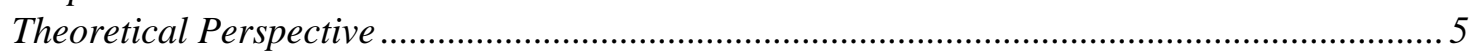

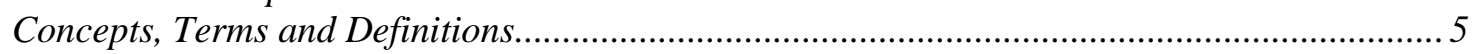

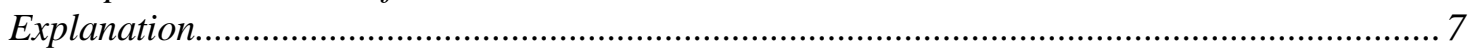

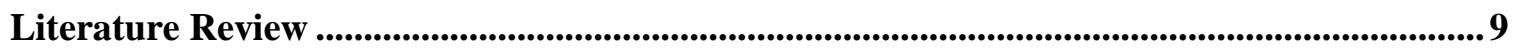

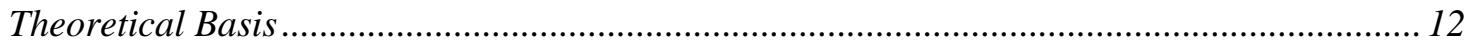

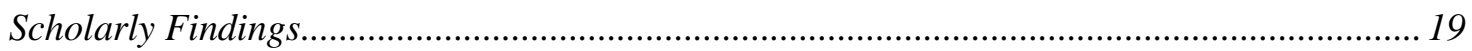

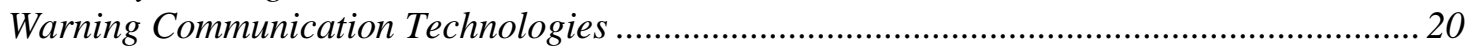

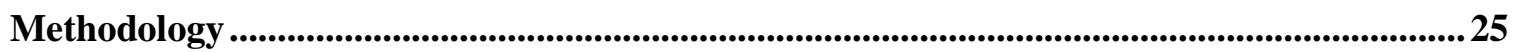

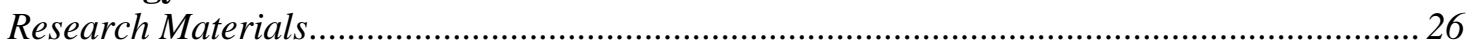

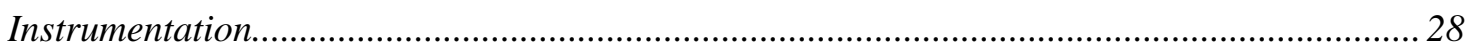

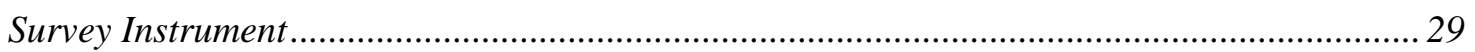

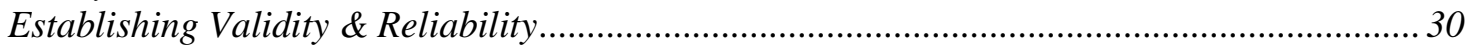

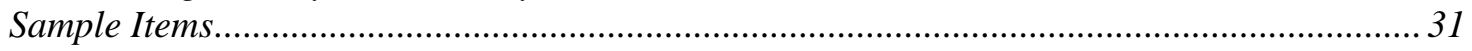

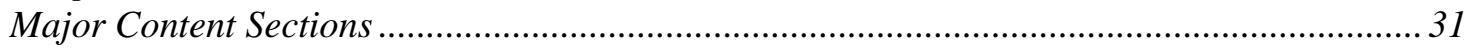

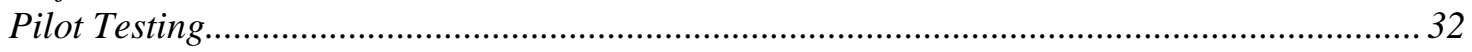

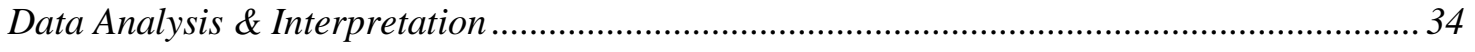

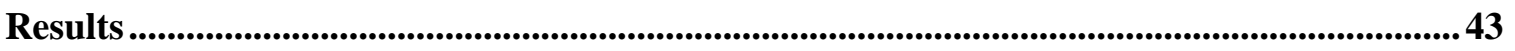

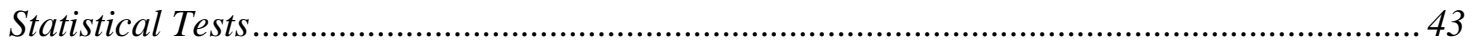

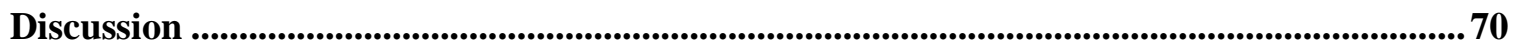

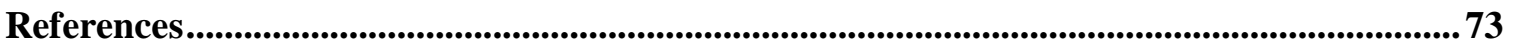




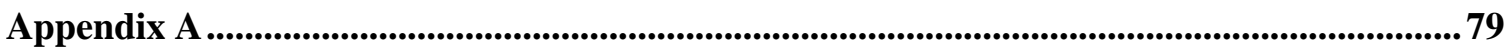

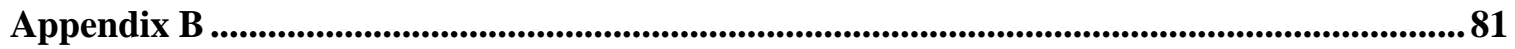

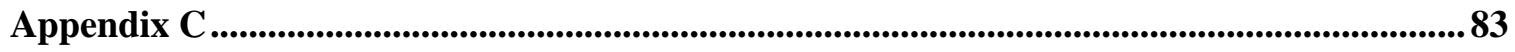

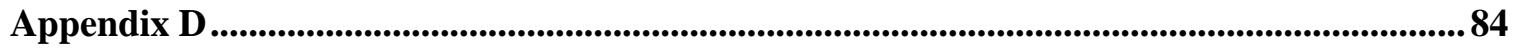

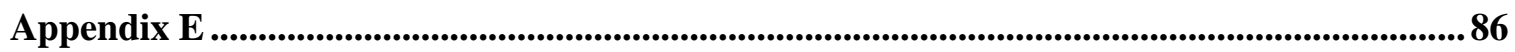

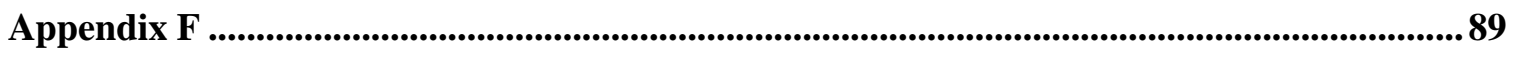

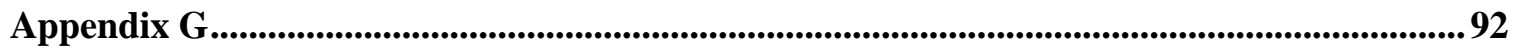

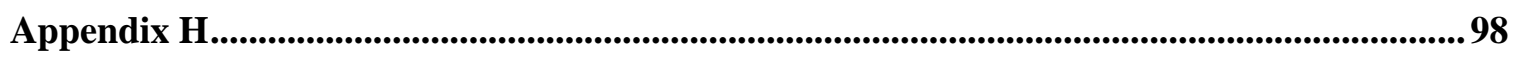




\section{LIST OF TABLES}

Table

Page

1. Palm Coast Crosstabulation Analysis of Age vs.

Receipt of Warning via Landline

2. Palm Coast Crosstabulation Analysis of Age vs.

Receipt of Warning via Cellphone. 45

3. Palm Coast Crosstabulation Analysis of Age vs. Receipt of Warning via TV ..... 46

4. Palm Coast Crosstabulation Analysis of Age vs. Receipt of Warning via Friend, Neighbor or Family Member

5. Douglas County Crosstabulation Analysis of Age vs.

Receipt of Warning via Landline.

6. Douglas County Crosstabulation Analysis of Age vs.

Receipt of Warning via Desktop computer, laptop or tablet

7. Douglas County Crosstabulation Analysis of Location Type vs.

Receipt of Warning via Outdoor Warning/Storm Siren

8. Douglas County Crosstabulation Analysis of Age vs.

Receipt of Warning via Neighbor, Friend or Family Member

9. Douglas County Crosstabulation Analysis of Location Type vs.

Receipt of Warning via Neighbor, Friend or Family Member 53 
10. Palm Coast Linear Regression of Education \& Income vs. Receipt of Warning on Desktop Computer, Laptop or Tablet as the Dependent Variable

11. Douglas County Linear Regression of Education \& Income vs. Receipt of Warning on Landline as the Dependent Variable.

12. Douglas County Linear Regression of Education \& Income vs. Receipt of Warning through Outdoor Warning/Storm Siren as the Dependent Variable 60

13. Douglas County Logistic Regression of Age vs. Prior Enrollment in CodeRED Weather Warning as the Dependent Variable

14. Douglas County Logistic Regression of Gender vs. Prior Enrollment in CodeRED Weather Warning as the Dependent Variable...................................................... 64

15. Palm Coast Crosstabulation Analysis of Prior Enrollment in CRWW and Confidence to Receive Future Warnings as Dependent Variable 66

16. Palm Coast ANOVA Table of Linear Regression 67 


\title{
THE EFFECTS OF NEW MEDIA FOR EMERGENCY TORNADO NOTIFICATION ON THE DIGITAL DIVIDE
}

Stephanie Meyers

Dr. Esther Thorson, Thesis Supervisor

\begin{abstract}
This study explored the possible continued existence of a digital divide as it related to how residents in two disperse communities received notification of late season tornado events in 2013. The theoretical perspective of the Diffusion of Innovations, Knowledge Gap and Structuration theories were used to examine how notifications were received based on socioeconomic indicators of total household income and education affected the ability for respondents to be notified of the impending danger.

Results varied for the communities surveyed, both supporting and negating how specific socioeconomic factors influence how respondents received notifications and the behavior they took after the message was received. Findings of the study indicate that higher total household income and higher education are often times associated with how respondents receive warnings of tornadoes in their area, but associations are not always consistent. Findings of this study show differences in how each community receives and reacts to tornado warnings.
\end{abstract}




\section{Introduction}

Technological advancements in media, including the ability for government agencies to deliver voice calls to cellphones, text messages, emails and social media have provided consumers additional communication channels to stay safe and informed both at home and on the go, compared to more stationary and traditional forms of media including radio and television. The ability to receive information through electronic media continues to be contingent on each individual consumer's access to technology, whether access is available at home, work or school. Smartphones have created the ability for many to access information in a mobile capacity through the Internet, including social media, photos, videos, emails and text messages, in lieu of traditional telephone calls to landlines.

Natural disasters like recent Superstorm Sandy have tested the capabilities of agencies charged with public safety in the way they deliver time-sensitive information to citizens within a specific jurisdiction during an emergency. Enhanced access to new media technology in a single solution has been made available through Web-based emergency notification systems (ENS). Traditionally, public safety officials were limited to relying on their local media to inform the community of a large-scale event - in which information was delivered at the mercy of the individual media outlet at a specific time and on a specific media platform. 
Organizations extending across K-12 communities, colleges and universities, local and state governments as well as federal agencies have begun to implement ENS into their emergency management plans as tools to effectively communicate critical information to massive audiences. A wide variety of vendors now exist to provide a large number of notification solutions ranging in price and feature set, offering both hardware and premise-based solutions that can effectively notify thousands of citizens within minutes. With these solutions, public safety officials have begun to implement the delivery of messages through mobile phone, text message, email and social media as part of a comprehensive emergency management strategy.

As new media are being used more frequently to deliver public safety messages to a wide audience, it is important to consider the implications of those within certain jurisdictions who simply do not have access to the technology to receive and interpret the information. Research has found that technology has paved the way for new methods of notifications (Moussavian, 2012), but only for those who have access. Access remains a hot topic in the public policy arena for those who see the Internet and other new media as a significant component of equity concerning access to information and resources (Rice \& Katz, 2003)

\section{Importance of the Question}

This topic is of importance as companies provide new technology that allows public safety officials to communicate in more modern ways. Several mass notification vendors provide a Web-based technology that allows government clients to send a large number of notifications via phone calls, text message, emails, social media and mobile apps in minutes. 
Since the advent of this technology, several public safety agencies have either eliminated more traditional means of communication, like outdoor sirens and PA systems, to exclusively use this new technology to notify their jurisdiction for both emergency and non-emergency alerts.

The new technology, though providing a more modern form of communication, does not always guarantee notifications can be delivered to vulnerable populations of a community, including the elderly, infirm or underprivileged. This research is not intended to discredit new technology that has been used very effectively during a crisis, but to determine how exactly people are being notified of impending danger and if a possible digital divide exists. This will be determined through the use of a telephone and Webbased survey, details of which are included in the Methodology section.

New technology has given both the average citizen and those charged with protecting the public new opportunities to communicate with each other in ways we never thought were possible. However, recent severe weather events like Superstorm Sandy and an outbreak of tornadoes in the Midwest have highlighted our dependence on these new media for emergency communication and the implications that dependence raises when new methods of communication are inoperable or inaccessible during a true crisis.

During these recent events, major telecommunications hubs were destroyed, almost completely eliminating the ability to access telephone and Internet. During Superstorm Sandy, record numbers of wireless calls were being placed which caused both local and national telecommunications resources to experience network congestion and outages. 


\section{Question Importance to Field of Journalism \& Mass Communication}

This topic is of critical importance to the field of journalism and mass communication because the concentration has been on the use of new communication technology, not on the actual receipt of the message and the subsequent action taken, if any, once the message was received. Emergency notification is different from the typical receipt of a general voice call or text message as typically there is a call to action, whether it is to seek shelter, shelter in place, prepare for the storm, evacuate or be vigilant. Journalists working in conjunction with emergency management practitioners should be aware of the limitations on the delivery of a critical notification in future efforts to help minimize harm.

As government "watch dogs," this topic is vital to reporters to cover as the government seeks to reduce the digital divide by providing funding and mandating wireless broadband networks in major cities across the country. The recently implemented Federal Emergency Management Agency’s Integrated Public Alert and Warning System is meant to deliver Presidential Alerts, Imminent Threat Alerts and AMBER Alerts, with limitations on those who receive the message based on their mobile carrier. Additional information on this national initiative will follow in the review of the literature. 


\section{Purpose Statement}

The purpose of this study is to determine the size and impact, if any, of the digital divide when it comes to receiving emergency tornado messages. Technology continues to present new, advanced methods of communicating but it has also created a modern day digital divide - separating audiences based on their ability to receive warnings through these new media to be informed of critical information that may impact their safety.

\section{Theoretical Perspective}

The theory of the digital divide, conceptualized using John Rawls' Theory of Justice, will be used as a basis for the research to determine if and how the disadvantaged remain marginalized through their inability to access new media for emergency notification (Hendrix, 2005, p. 65). From a theoretical standpoint, the digital divide is understood as a public problem, a way to frame and to measure inequality in the information society (Sacchi, Gianni, Bochic, Reinhard, \& Lopes, 2009).

\section{Concepts, Terms and Definitions}

Digital divide, digital inclusion and digital reception. The digital divide will be defined as differential access to and use of new media in general, according to gender, income, race and location (Rice \& Katz, 2003). More modern research tends to use a new term, coined "digital inclusion," to define initiatives that aim to include people usually restricted in their use of technology for societal or health reasons (Digital Inclusion, 2010). It is also used to describe projects that have attempted to provide people physical access to IT resources and enough proficiency to use them to increase their knowledge base (Sacchi, Gianni, Bochic, Reinhard, \& Lopes, 2009). 
The term digital reception will be used to define the user's ability to receive an emergency tornado broadcast via a digital media device including a cellphone.

Emergency notification systems. Emergency message transmission is defined as an alert initiated and delivered through the use of a Web-based ENS. There are a variety of ENS solutions provided by private vendors for use by public safety officials representing government organizations. CodeRED is a mass emergency notification system provided by Emergency Communications Network (ECN). CodeRED is one of many available Web-based ENS solutions used by public safety officials. Messages are initiated by a local authority and delivered to the entire community or specific geographic areas. CodeRED Weather Warning, a service of ECN, is an automated severe weather warning solution that alerts residents in the path of severe weather by telephone call, text message and email. CodeRED Weather Warnings are initiated by the National Weather Service without any human intervention required to deliver notifications. CodeRED Weather Warning is an opt-in service; notifications are delivered only to those who have subscribed. Both CodeRED and CodeRED Weather Warning notification solutions are purchased by a city, county or statewide public safety agency and are provided to residents within that community at no charge.

New media. For the purpose of this study, "new media" is defined as new devices, including cellphones or smartphones that can send or receive text messages and voice calls in a mobile setting. New media will refer to the devices in which emergency tornado notifications are received. 
Access. Access is defined as the recipient's ability to receive an emergency tornado warning. Warnings may be received through either a home or work wireless mobile device to include flip phones and smartphones. Access to voice messages and text messages are defined as the recipient's availability to receive such messages through a personal cellular device.

\section{Explanation}

With the availability and adaptation of new technology, receivers sometimes treat the medium itself, including computers and television, as an autonomous source worthy of social attributions (Sundar \& Nass, 2001,pg. 54). The source of the emergency notification is the public safety entity that initiates the alert to share with the affected population, though the medium as a voice call or text message is the actual method in which the message is received.

Using an ontological point of view (Sundar \& Nass, 2001,pg. 54), the source is distinguished between a "channel communicator" to include the new media in which information is received, an "internal" source to include the public safety official and an "external" source to define the delivery of the emergency message transmission through a Web-based emergency notification solution.

Similar to a news transmission, the sender is the public safety official employed by a city, county or state government entity who gathers the information needed for the information transmission. The sender has to receive the information from another source from within their organization in which they are employed, trim the information to fit inside the technology channel and then disseminate the information for mass or targeted consumption, depending on the emergency situation at hand. 
The emergency message is then delivered through a technology channel, through voice calls to cellular devices as well as text messages. Completing the communication chain are residents or visitors of a specific geographic area who hear or read the information and take action, if suggested or required by the sender for their safety. As technology is the primary area of research as it relates to access, the concept of the receiver as a source versus technology as a source (Sundar \& Nass, 2001, pg. 55-57) will be studied to determine access to emergency notification as it relates to their choice of what information to consume, and their accessibility to consume information delivered by new media.

The purpose of the research, followed by definitions, concepts and terms have been provided as well as an explanation of the research. Soon it will be demonstrated how the research was developed through a review of the literature. Before that, however, the literature review will be introduced in abstract and justify the use of a communications theory. 


\section{Literature Review}

This literature review explores the theory and existing scholarly literature about digital inclusion as it relates to citizen's access to receive emergency information from various communication methods. The focus of the research revolves around the changing methods in which emergency information may be received and the implications of access when it comes to the ability to retrieve the emergency broadcast. The analysis is distinguished from other scholarly endeavors on the topic by considering the terminology of the digital divide as it relates specifically to emergency notification, methods of communication and to direct future work in this critical communication access issue.

The idea of the digital divide, or the separation of the "haves" and the "have nots" is a concern when it involves the ability to access information in times of emergency. An adequate warning system must distribute the tornado warning through an extensive communications system, so that the public can make appropriate reactions to save lives (Bradford, 1999). As it relates to severe storms, one of the earliest tornado warning system propositions included the continuous ringing of a bell when a wind of destructive force (the proposed wind force was $70 \mathrm{mph}$ ) was approaching, giving adequate opportunities for those in harm's way to seek shelter and save their lives (1999). More recent and traditional early alerting methodology has involved the use of a siren, alerting communities of impending disaster with a loud noise and the ability to alert an entire geographic area simultaneously (Collins \& Kapucu, 2008). 
The efficacy of sirens is contested, with sirens that fail to warn citizens of impending danger or that are regularly ignored when initiated. In 2006, a malfunctioning generator and failed battery were the reasons that 18 of Alpharetta, Georgia's 19 emergency warning sirens failed as tornadoes rolled through the city (Pearson, 2006). Elsewhere in Georgia, a resident said she had heard so many storm sirens in her neighborhood that she started to ignore them (Payne, 1998). There are also differing opinions on when the sirens should be turned on, with one emergency management official warning people of severe thunderstorms while others disagree, refusing to turn on sirens unless a tornado has been actually sighted (1998). New technology including integration with National Weather Service feeds allows the automation of emergency messages to include telephone calls to land and cellular telephones, text messages and emails to those within the exact area of impact.

However, variables such as education, income and the perception of vulnerability tend to correlate with the citizen's preparedness (Bethel, Foreman \& Burke, 2011) even as advanced technology in early warning has provided a multi-method method approach to notification. The speed of access to information must be considered as an important variable in user/community typologies (Modarres 2011, pg. 5). The divide becomes a three-layered phenomenon of access, information creation and information usage, with the continuing danger of division along race, class and ethnicity (Modarres 2011, pg. 6) The digital divide is concerned not so much with technology as with its "significant societal ramifications" (Gunkel, 2003 p. 509) and in this specific research, the results of relying on newer methods of communicating when not everyone has access to the messages. 
Gender and race also play a role before, during and after a disaster. Morrow, as cited by West and Orr (2007) indicated that women are less likely to have access to official information that might enable them to assess disaster risks, making it more difficult for them to respond to disaster scenarios (2007). When it comes to ownership, a 2010 study of 1,100 women and men indicated that all of the respondents had cellphones, $70 \%$ of women owned a desktop computer compared to $80 \%$ of men and $34 \%$ of women owned a laptop compared to 47\% of men (Demiray, 2010). However, a 2012 Pew Research study focused on age groups found that 88 percent of all adults 18 and older owned a cellphone (Zickuhr, 2012). Women and minorities do not always act differently from men and Whites in all situations, but they do in particular situations (2007). The perception of hazard to race and gender effects differs from financial resources and being married among other factors (2007). A 2007 study found that women are 10 percentage points more likely than men to say they would obey a government evacuation order, whereas minorities are 27 percentage points more likely than Whites to say they would evacuate if recommended by the U.S. Weather Service (2007).

If the public believes it is necessary and has received appropriate information in a timely manner, it is reasonable to expect that they will take action to protect themselves (Spence, Lachlin, \& Griffin, 2007). However, mobilizing information, or information that provides cues to action on how to behave in response to a disaster, provided by local television news organizations did not provide the necessary cues to facilitate behavioral change as pertaining to emergencies (Tanner, Friedman, Koskan, \& Barr 2009). 
Gladwin \& Peacock, as cited by Spence et. al found that evacuation before Hurricane Andrew was the lowest among African Americans and Hispanics. Nonminorities and people of higher socioeconomic status are usually better prepared for disasters than others (2007).

\section{Theoretical Basis}

Research into the digital divide has traditionally focused on race and ethnicity, age and geographic location. More recent research has determined that income, education and employment also play a large factor in access to newer forms of media (Sipior, Ward, \& Connolly, 2011). Lower income and more marginalized neighborhood information communication technology (ICT) use remains largely for specific purposes and switched off as the information sought has been obtained. In affluent neighborhoods, however, ICT use is first used by individuals evolving into collective communities since distance is not a limitation (Crang, Crosbie, \& Graham, 2006). ICTs can facilitate faster connectivity as a privilege of mediated access (2006). Although the term digital divide is most often referred to as the division of technology "haves" and "have nots," the basis of the disconnect or inequality has been attributed to two major communication theories, including the Diffusion of Innovations Theory and Structuration Theory (Mason \& Hacker, 2003 p. 45 and 48).

Diffusion of Innovations Theory. Everett Roger's 1986 theory developed the model of how people undergo a series of processes in which they accept innovations, where the consequences of adopting a new innovation are alternatively categorized as desirable or undesirable, direct or indirect or anticipated to unanticipated (Heath, $2005 \mathrm{p}$. 253). 
Roger's rationalized that those "change agents" or in the case of emergency notification for this research, public safety officials who decide on what medium to disseminate an emergency message are better educated and are of higher socioeconomic status than the people they attempt to influence (2005).

As new communication technology, or the ability to receive notifications from a local public safety agency through their use of an emergency notification system, is generalized to be acquired and used by a very few at first, much of the population then reaches a high rate of adoption with a few late adopters (Mason \& Hacker, 2003 p. 46). Rogers, in an interview with Deone Zell, rationalized that in general, innovations that have no profit motive diffuse slowly, even though there is no doubt about the benefits of the innovation if it were adopted (McGrath \& Zell, 2001). In his interview (2001), Rogers also indicated innovations that are preventative - one that has to be adopted now to avoid future problems - generally diffuse much more slowly than those innovations that are not preventative. When it comes to emergency notification through the use of new media, there are new communication methods that allow more people to have earlier warning and access to additional information that may protect them from harm. Rogers' research indicates that the solution, however, does not diffuse very rapidly (2001).

Rogers' research points out a critical issue regarding communication innovations; that while the innovation represents a new way to contact other people, the other person has to also have adopted the technology which in turn creates a special momentum that allows the diffusion process to begin (2001). For this research, the innovation is the emergency notification system and the adopting of technology represents the local community enrolling to receive notifications from the public safety agency. 
When emergency notification specifically for the purpose of early warning for tornadoes is considered, for example, the issue becomes three-fold: (1) innovative technologies allow the delivery of early warning for severe weather, (2) a government agency tasked with providing such warning to citizens must have adopted the service to provide their community and (3) citizens must have the proper devices to receive the message and enroll to receive future notifications. The second point is turnkey and without the adoption of the innovation, diffusion may never occur within that specific geographic location.

Rogers' theory also discusses the perception as part of the diffusion process; the more we perceive that many people are adopters of an innovation, the greater the momentum for us to adopt as a "reverse-flowing" benefit (2001). The process reveals the advantages of a communication innovation as it diffuses as with each further adopter; the innovation becomes more valuable to not only future adopters but to all past adopters as well (2001).

In this example and for this specific research, Rogers' use of the word "people" may be more appropriate to assign to the public safety organization as the initial adopter of the innovation to share the emergency message. Initial adopters may be agencies that have already implemented an ENS and are utilizing the innovation to reach citizens through text message and voice calls to cellular telephones. As new ENS are put in place, other public safety communities see how the innovation has been used, sees its value and begins the diffusion process on their end to implement the innovation in their specific geographic location. 
This was the case for the City of Bullard in Florida, whose city manager decided to implement an ENS following interviews with other cities utilizing an ENS system including the nearby cities and counties of Tyler, Smith, Chandler and Jacksonville (Harper, 2011).

On the side of the receiver, there are several tasks involved to receive an emergency notification. First, the general public must own the device for delivery. The resident must also have the understanding that they may receive a warning message through that device. Finally, the resident must know to respond to the instructions being delivered to that device, for example to take shelter. In the case of the use of new media for emergency notification, the consequence of not receiving information on a mobile device as the method of choice may have more to do with inability to accept the technology due to societal factors outside of the receiver's control.

Knowledge gap hypothesis. The term knowledge gap is being used to define the digital divide, as a gap between those who can effectively use new information and communication tools and those who cannot (Wei \& Hindman, 2011). However, knowledge gap does not only relate to only a difference in knowledge. Gaziano, as cited by Mason \& Hacker (2003) hypothesized that as more mass media information circulates through society, those in higher socioeconomic categories acquire at faster rates than those at lower levels. The digital divide, then, can be thought of as a knowledge gap situation where as more information becomes available, the "haves" consume the information faster and take action as needed, whereas the "have nots" make less use of the information they receive and therefore take less action. The "haves" are more likely to be aware of the existence of a notification system in their community. 
The "haves" are therefore also more likely to have enrolled in the notification system to receive future warnings so they may be informed of emergency events that may affect their safety. Gaps beyond basic access, including skill level, opportunities and comfort affects technology use and frequency of technology use (Mason \& Hacker, 2003 p. 47).

The knowledge gap may reveal possible negative outcomes when it relates to a citizen's knowledge of a tornado threat and any preparations they took before the storm. Knowledge gap studies reveal that over time, the college-educated acquired more knowledge as compared to the less educated (Spence, Lachlan, \& Burke 2011). Those with preexisting knowledge may have advantages over those who do not (2011). Additionally, women may tend to translate a relational orientation (i.e. "concern for family") into a problem-solving orientation (i.e., "what information do I need to reduce the possible harm to my family?") (2011). In research examining information seeking and the September 11 attacks and Hurricane Katrina, women reported being more interested in engaging in more general information seeking than men (2011).

Structuration Theory. Structuration Theory suggests that people with more resources can achieve their desired ends more readily than those with fewer resources (Mason \& Hacker, 2003 p. 48). Technology is used in ways to increase the resources of the users (2003). Those who adopted the use of new communication methods to receive information in more modern ways have the resources and skills to continue to use and receive information from the technology. The unintended consequence is those without the resources fall further behind. Those with the most access will have influence and benefits that are unavailable to those without. 
Together, Structuration Theory with Diffusion of Innovations and knowledge gap provide a theoretical and methodical approach to understanding why differential use of, access to and resulting action taken after receiving the message vary from one socioeconomic status to another. Diffusion of Innovations is the beginning of the process, in which the resident as the receiver must accept the communication device, adopt it through purchase and use and then see the value of being able to receive emergency messages through that specific device. Once the value is seen, diffusion begins to occur to spread among others to use the technology in a similar way. Such is the case after a series of severe storms, where enrollment in notification systems surges as diffusion spreads rapidly among a community who want to receive future warnings.

Knowledge gap is a continuation of the process and picks up at the diffusion stage. The richer with more means will acquire the available technology faster and enroll to receive warnings, ultimately being able to receive information sooner than those who may not be aware of the availability of an early warning technology for their community and therefore would not be enrolled to receive such warnings. Structuration Theory is the final, but ongoing part of the process in which the richer will continue to achieve what they desire more readily and in this research, ultimately be more informed of emergency events that may impact them.

John Rawls' “A Theory of Justice” was originally published in the 1970s. As it relates to the digital divide, Rawls' argues for liberty and equality. Rawls' quest for the principles of justice specifies that although all the other goods can be shared unequally (under certain conditions), liberty must retain equal distribution (Duff, 2010). 
As long as there is equal opportunity, or in information society terms, equal access to gain such goods as a level start, the resulting pattern of distribution can be regulated by the "difference principle" (2010) or the diverging of a strict equality to make the least advantaged in society materially better off. The disadvantaged remain marginalized; one group has more opportunities and funding than another group that creates real inequalities through injustice (Hendrix, 2005, p. 64)

People would logically engage in decisions that help themselves and injustice would not exist because it would not be reasonable under the "veil of ignorance" (2005). Rawls' theory disrupts the methodical process of the earlier theories because in his quest, there should not be inequality when it relates to equal access in an information society. Therefore, the process linking the previous three theories cannot exist as part of his thought if all goods are to be shared equally.

During an emergency situation, all people have in some sense a kind of inequality that might be caused by lack of information (Malizia, Onorati, Diaz, Aedo, \& AstorgaPaliza, 2010). Emergency information systems generally do not include information and knowledge about different kinds of users to be notified about an emergency and there is a failure to take into account differences in accessing the information sources or available resources depending on the abilities of the receivers (2010).

These theories will be used as a basis to determine the following: Collectively, does the diffusion of information, knowledge gap and structuration theories support a receiver's adoption and use of new media for emergency tornado information and the action a receiver takes, if any, once the message is received? 


\section{Scholarly Findings}

Although there are many diffusion research studies, none currently relate to the topic of emergency notification and the use of technology on behalf of public safety organizations to disseminate time-critical information. As it relates to Rogers' Diffusion of Innovations, Rogers found among many diffusion problems, that an innovation appears to be beneficial and appears to have benefits to its users but does not have very many users (McGrath \& Zell, 2001).

The goal then is to speed up the diffusion process to maximize the possible benefits to the adopters of the technology. A review of the existing literature will focus on innovations in communication technology as it relates to its use for emergency notification of tornadoes.

Background. Tornado warnings are issued by the National Weather Service and are then communicated to the public through a variety of methods including storm sirens, public radio, television, weather radios, the Emergency Alert System, the Internet and wireless telephones. Additionally, warnings through cellphones, text messages and emails may be automatically initiated through the service of an ENS that individual public safety agencies pay additional fees to offer their individual citizens. The timely dissemination of warnings is critical to the protection of life and property (TORNADO FORECASTING AND WARNING, 2006).

Success of a warning program hinges on the public's ability to respond quickly and properly to the information presented (2006). It also hinges on the public's ability to correctly perceive the threat and respond by actions that will provide safety (2006). 
Therefore, differential access to the technology because of income, education, race and gender may have created an unintentional digital divide for emergency tornado messaging.

\section{Warning Communication Technologies}

Outdoor warning sirens. Outdoor warning sirens resulted in response to a threat of enemy attack on the United States with atomic bombs and the President at the time, Harry Truman, issued legislation that provided federal support to state for defense equipment, including public warning sirens (Coleman, Knupp, Spann, Elliott, \& Peters, 2011). It is not known exactly when sirens began being used for weather warnings, but by the 1960s they were being used fairly regularly to warn residents of impending tornadoes (Laidlaw, 2010). Sirens originally sounded a long single note or tone alert to indicate tornado warnings and now use various tones, alerts and wails (2011).

Activating outdoor warning sirens is an effective way of warning people who are outdoors and are useful if power or telephone lines fail or malfunction during a severe weather outbreak (Durage, Wirasinghe, \& Ruwanpura, 2013). Research conducted by Durage et. al (2013) indicates that many tornado-prone areas in the United States have full siren system coverage (2013) but similar research negates those findings (Coleman, Knupp, Spann, Elliott, \& Peters, 2011).

Limitations of technology. Outdoor warning sirens are a unique part of the tornado warning dissemination process, however some small towns and rural areas do not have outdoor sirens and there are variables of the sound level of the siren (for example, whether the person is indoors or outdoors, the person's distance from the siren) (Coleman, Knupp, Spann, Elliott, \& Peters, 2011). 
Sirens are not meant to permeate into buildings; instead they are meant for people outside to be warned of the impending danger (McKoppin, 2003).

Though the National Weather Service issues tornado warnings, it is up to each public safety agency to decide whether or not to activate their sirens (2003). There is no state or nationwide requirement for activating the sirens so the decision rests on the individual city or county agency to initiate the siren (2003). What may be siren initiation protocol for one city or county inside a specific state is not protocol for a city or county in another state. Therefore citizens who may become accustomed to hearing a siren in one area may be disadvantaged if they travel elsewhere.

As a hardware technology, maintenance costs pose limitations to the agency issuing and charged with maintaining the siren. A county emergency management director, interviewed in the Tribune Business News (Neeley, 2011), indicated costs for a telephone emergency notification system were minimal compared to installing 217 sirens at $\$ 15,000$ each, which did not include maintenance. "Weather sirens are fairly useless in North Carolina," the official was quoted saying by the Tribune reporter (2011).

Little research exists about how citizens actually confirm acknowledgement of hearing a tornado warning disseminated through an outdoor warning siren. Unlike Webbased warning technology that can track the actual delivery and receipt of individual persons or groups receiving a warning, a survey would likely need to be conducted to determine who heard the siren, when and how much warning it was able to provide.

Mobile telephone warnings. Sending weather warning information through mobile telephones is a relatively new application (Durage, Wirasinghe, \& Ruwanpura, 2013). 
Mobile telephone users may receive warning information as mobile text alerts and those with smartphones may receive warnings through social media including Facebook and Twitter (2013). Through an emergency notification platform, residents may automatically be called when severe weather warnings are issued for tornadoes, severe thunderstorms and flash floods for the person's address. The notifications are sent automatically to the telephone number residents have entered and are sent year round, 24-hours a day (Neeley, 2011).

Wireless Emergency Alerts. A recent initiative by the federal government has provided emergency messages sent by authorized government alerting authorities directly through the user's mobile carrier (Department of Commerce, 2013). Through Wireless Emergency Alerts (WEA), users may receive extreme weather warnings from the National Weather Service, including tsunami warnings, tornado and flash flood warnings, hurricane, typhoon, dust storm and extreme wind warnings as well as blizzard and ice storm warnings (2013). Messages are broadcast from cell towers to mobile devices in the area of the threat.

Limitations of technology. Mobile communications can be severely affected by adverse weather by those facilitated by cell towers, and most cellphones send and receive signals directly to and from cell towers (Wing, 2012 pg. 40-41) Some mobile devices, especially older devices, are not WEA-capable. A 2012 report found that only about 10 percent of cellphones in use were equipped with WEA software (Norvell, 2012) although the National Weather Service expected that by 2014, all phones on the market will be WEA capable (2012). 
An alert may reach cellphones outside of the actual warning area depending on the broadcast range of the cell towers that broadcast the alert (Department of Commerce, 2013). Overreach is more prevalent in rural areas than in more densely populated cities (2013).

Limited research exists of how citizens, or anyone for that matter, actually confirm acknowledgement of hearing a tornado warning disseminated through a mobile device. A study published in 2001 was established to understand the disconnect between desired and actual response of college students during severe weather to determine if and how a university community actually received the tornado warning and what people did upon receipt of the message (Sherman-Morris, 2009). No scholarly research appears to exist to determine this same information for individual communities.

Mobile telephone usage. Mobile phone adoption appears to be surpassing the popularity of television sets on a worldwide basis and in the United States, people who have only mobile phones amounted to 4 percent of all telephone subscribers (Rice, 2003). A 2013 Princeton Survey Research Associates International study found that $91 \%$ of American adults own a cellphone and of that amount, $81 \%$ send or receive text messages (Maeve, 2013). Studies indicate that mobile phone users, compared to nonusers, were more likely to have full-time jobs, higher income and be currently married (2003).

Much of the available scholarly literature regarding tornadoes and the use of varying communication technologies to provide early warning to citizens focuses on the transmission of the warning, whether the warning is issued by outdoor sirens or through new technology including direct warnings to mobile subscribers by voice calls and text messages. 
There is little research on whether there is actual receipt of the warning messages. There is also little research on what agencies should consider when utilizing technology to provide early storm warnings to citizens in the affected area of the alert.

In a study conducted at Mississippi State University, a survey appears to be the only scholarly undertaking to determine a student's receipt of a tornado warning via cellphone, instant message or email through the campus "Maroon Alert" emergency alert messaging system. Sherman-Morris (2009) found that cellphones were the most common means of receiving a tornado warning and that $85 \%$ of respondents heard about the possibility of severe weather through the "Maroon Alert" message sent earlier.

A review of the literature has helped form the basis of the study. Next, the methodology will explain the research questions and hypotheses and the manner in which they were answered. 


\section{Methodology}

The purpose of the study is to determine if citizens impacted by a tornado in November and December 2013 in specific geographic areas had prior knowledge of the weather threat, what medium or media they used to receive the tornado warning and any follow-up action taken to be compliant with the message instructions. These dependent variables will be examined as a function of SES, gender, income and race. These questions will help determine if a digital divide exists between members of different socioeconomic statuses as it relates to their receipt of emergency tornado messages and behavior taken after they received the message.

Research Question: What SES and demographic differences existed in the surveyed sample's receipt of an emergency tornado warning on various communication devices?

The following hypotheses were tested with the survey:

1. Citizens of a higher SES will have indicated they knew about a possible tornado threat to their community prior to when the tornado hit on November 17, 2013 or December 14, 2013 more than those of a lower SES.

2. Citizens of a higher SES will have received emergency tornado warnings on more communication devices than those of a lower SES.

2a. Citizens of a higher SES were more likely to have enrolled to receive emergency tornado notifications through their community's CodeRED Weather Warning service than those of a lower SES. 
2b. Citizens who were registered for their community's CodeRED Weather Warning service prior to the tornado were more confident they would receive future warnings in time to be safe more than those who were not in CodeRED Weather Warning prior to the tornado.

3. Citizens of a higher SES will be more likely to have taken action to relocate to a safe place after receiving the emergency tornado alert more than those of lower SES.

Asking respondents a series of demographic questions, including personal and household income, as well as level of education completed operationalized socioeconomic status. There is no universal measure for socioeconomic status, therefore the researcher assumed valid SES indicators by asking respondents a series of categorical questions regarding highest level of education completed along with individual and total household income categories. As inferences were made about how people received warnings, a survey method was determined to generalize the sample to a larger population and would provide a quantitative description of trends of a population (Creswell, 2009).

\section{Research Materials}

The population and sample. The survey sought citizens located in the United States where a tornado threat affected their community in 2013. The National Weather Service (NWS) tabulated 941 tornado reports in 2013, 111 of them occurring in November with 106 of the tornado reports from November 17, 2013 (2013, December 1). Additionally, the NWS tabulated 16 tornado reports in December 2013, with a single report indicated on December 14, 2013 (2013, December 1). 
For this survey, the researcher selected two communities listed in the November 17, 2013 and December 14, 2013 NWS tabulation with confirmed tornado reports that were also current clients of Emergency Communications Network (ECN) and use the company's Web-based notification system, CodeRED, to be the population concentration for the survey. A recent tornado event was determined to be the best incident to ask questions about, because tornadoes in both communities caused significant damage and would be memorable to those who participated in the research.

Selection process. A convenience sample was used for the survey. Because a specific year, month and date were the concentration of this research, it was important to select those citizens who were affected by a tornado threat associated with the designated year, month and date so inferences could be made to communities of similar size to gauge a citizen's ability to receive emergency tornado alerts.

Inclusion criteria. Inclusion criteria confirmed that only those who were affected by the tornado warning were eligible to participate in the survey. Characteristics used in inclusion and exclusion of the survey sample included the following:

(a) Gender: Male or female participants

(b) Location: Must have resided in the location listed in the NWS tornado tabulation

(c) Time Frame: Participant must have resided in area listed in the NWS tornado tabulation during a tornado threat on November 17, 2013 or December 14, 2013. 
Procedures for selecting the sample. Agencies currently using a Web-based notification system provided by ECN, a provider of emergency notification solutions, whose location name was listed in the NWS tabulation for a tornado on November 17 , 2013 or December 14, 2013 were asked to help engage their citizens to participate in the survey. The selected agencies were the City of Palm Coast, FL and Douglas County, IL. The researcher leveraged the existing relationship the agency had with ECN and the findings of the research would benefit the agency in terms of building understanding of communication limitations or challenges within their individual jurisdictions. The existing relationship with the agency guaranteed the researcher access to an agency contact, including email address and mobile telephone number to request their participation in the research.

Sample Size. In 2010, the United States Census Bureau estimated the population of Douglas County, IL at 19,980 and Palm Coast, FL at approximately 75,180 (2010). Both communities use the CodeRED Weather Warning system, which sends automated tornado warnings to citizens within the direct path of the storm to those who have subscribed to receive alerts. To provide for a sampling error of about plus/minus $2 \%$, the sample size was 1,000 citizens. To attain 1,000 responses, the researcher solicited the help of these agencies for participation to share the survey invitation with their citizens through media coverage.

\section{Instrumentation}

Based on the need for citizen feedback from specific geographic locations distant from the researcher's actual location, an online survey and automated telephone survey were determined to be the best methods to answer the research question and hypotheses. 
An online survey was cost-effective and results were received quickly without the need for manual coding or manual data collection. An online survey allowed the researcher to ask a variety of questions in a highly efficient and economical way.

As of April 2012, approximately 66 percent of adults 18 or older have home broadband connection to access the Internet (Zickuhr, 2012). However, to seek citizen participation from those who may not have Internet access to complete the online survey, or to those who would prefer taking the survey over the telephone for other reasons, the researcher also made available a toll-free telephone number for the respondent to call in to complete the survey. The City of Palm Coast, FL and Douglas County, IL were assigned two distinct toll-free telephone numbers so the researcher could distinguish the data. The automated telephone survey was created and executed using ECN technology, in which the researcher recorded the survey questions, giving respondents the ability to push buttons on their touchtone telephone to indicate their response (i.e., press 1 for yes, press 2 for no).

\section{Survey Instrument}

The Web-based survey instrument used to collect data for this research was Qualtrics, a premier online survey tool. Qualtrics is an intact instrument developed by the company itself and they provide an enterprise data collection and analysis service that is utilized by every major university in the United States (2013, About us). Qualtrics was recommended for use in this study because it had additional tools compared to SurveyMonkey, and the University provided free student access to the service. 
The automated telephone survey instrument to collect data for the research included an interactive voice response recorder, two toll-free telephone numbers owned by ECN and telephone lines provided by ECN. Programming of the surveys was completed by ECN staff, including a database administrator to set the parameters in which the data would record electronically, a production manager who recorded the researcher's voice for survey questions and set the audio files for the survey and the Vice President of Operations who created and implemented the coding of the automated telephone survey to execute the research. All work provided by ECN to execute the telephone survey was provided free of charge in support of the researcher's continuing education.

\section{Establishing Validity \& Reliability}

Validity. To ensure the survey measured what it was supposed to, all participants were encouraged only to participate in the research if they lived in either Douglas County, IL or Palm Coast, FL where a tornado threat was indicated in November 2013 and December 2013, respectively. The invitation to take the survey, as well as the introduction of the survey itself, made it clear to the potential respondent that only those who met those specifications should complete the survey. Validity was ensured by providing separate toll-free telephone numbers to the public of the participating communities to distinguish the data as coming from one or the other community.

Reliability. To ensure the survey measured something consistently, citizens in both Douglas County, IL and Palm Coast, FL received the same online survey. The questions appeared in the same order, on the same pages and were estimated to take approximately the same amount of time to complete. 
The online survey was executed through Qualtrics using the same survey theme to ensure that a true comparison could be made. Participants were asked to take either the Webbased survey or the telephone survey, not both.

To ensure the telephone survey measured something consistently, citizens in both Douglas County, IL and Palm Coast, FL had the opportunity to call in and take the automated telephone survey. The only differentiator between the online and telephone surveys was the indication in the text and audio of the community in which the tornado threat took place. The community name was clearly noted in the survey and only those impacted by a tornado threat received the survey specific to the tornado incident. Additional reliability was assured through consistent test administration and scoring.

\section{Sample Items}

Questions used on the Qualtrics questionnaire allowed readers to see the actual survey questions used in the research. The researcher created the survey questions that comprised the online and telephone-based questionnaires included as appendices to the research.

\section{Major Content Sections}

The online survey contained a cover letter as the first page, including the survey title, the purpose of the study and how to contact the investigator, followed by a welcome, reminder of the tornado incident the survey would seek feedback and who the survey was meant for. Questions related to how they received the tornado warning, as

well as demographics, finishing with a survey closing thanking participants for their time and feedback. 
Supplemental questions following the survey closing were optional, but highly encouraged to complete to those taking the online survey to provide additional feedback on attitude and behavior related to the tornado warning. The survey contained multiple choice answers to questions as categorical scales and continuous scales that measure attitude. Questions in the survey asked the recipient to determine how specifically they were notified of a tornado threat through all of the available devices to them, and solicited feedback from the respondent on what action was taken, if any, after the message was received.

The telephone survey began with audio introducing participants to the survey with the survey title, the purpose of the study and how to contact the investigator, followed by a welcome to the respondent and thanking them for their time. Questions followed in sections, asking the respondent to indicate a key press of their answers (i.e. press 1 for male, press 2 for female). All questions required a key press for the respondent to indicate their response. Like the online survey, telephone survey respondents were asked simple "yes" or "no" questions to answer. Due to the anticipated length of time to complete the survey over the telephone and to avoid respondent fatigue, supplemental questions were not included in the phone survey.

\section{Pilot Testing}

A pilot test of the online and telephone survey was distributed to the agencies themselves that were selected and agreed to participate. 
The point of contact for the survey as established by ECN, and any additional interested parties at the agency within the public safety and emergency management division, were asked to review and test the survey to establish the content validity and ensure the questions, format and scales were appropriate for the most accurate and reliable citizen feedback. Based on feedback received from those who took the pilot of the survey, one revision was made to the survey before deployment for the actual data collection period. The feedback received was grammatical in nature; no changes were requested to the questions, available responses, question ordering or survey execution.

The approach to generate survey interest and respondents from geographically disperse communities was the local media. Palm Coast, FL is considered part of the Orlando-Daytona Beach-Melbourne, FL media market, the $18^{\text {th }}$ biggest media market in the United States (Local television market universe estimates, 2013). Because proximity wise Palm Coast is more than one hour away from Orlando and therefore Orlando-based media is not always available to cover Palm Coast related news stories, Palm Coast has a large variety of local media organizations including radio stations, newspapers and online news organizations. Douglas County, IL is considered part of the Champaign \& Springfield - Decatur television market, ranked $84^{\text {th }}$ out of 210 total markets, providing media coverage to $382,050 \mathrm{TV}$ homes (Local television market universe estimates, 2013).

The researcher provided the agency an initial news release template (Appendices A and B) and a follow up news release template (Appendices D and C) to share with the media and with participating citizens. On Monday, February 3, 2014 following final IRB approval, the researcher requested both clients distribute the initial news release to media organizations in each of their media markets. 
The research study received extensive media coverage in Palm Coast, FL, including known coverage by the following news organizations: Central Florida News 13 - TV, WNZF, News 1150 WNDB, Flaglerlive.com, The Palm Coast Observer, The Daytona Beach News Journal and The St. Augustine Record. Media coverage in Douglas County, IL included the following news organizations: WAND-TV and The News-Gazette. The story also garnered the interest of Emergency Management Magazine and was published in their Emergency Management blog. The Palm Coast Chamber of Commerce republished the initial press release on their website.

Due to the large amount of feedback received from Palm Coast, FL as the survey neared completion, and fewer responses received from Douglas County, IL, the researcher did not request Palm Coast to distribute the follow up news release template, which was written to generate additional responses before the survey ended. Douglas County, IL was asked to distribute the follow up news release to their local media, requesting a fax and email version of the news release was shared with local media outlets. The follow up news release generated additional news coverage in Douglas County via coverage on WAND-TV.

\section{Data Analysis \& Interpretation}

The following information details the steps involved in analyzing the data collected during the 2-week research period, which began at 12:01 a.m. on February 3, 2014 and concluded at 11:59 p.m. on February 17, 2014. On the morning of February 18, 2014, the researcher deactivated each of the Web-based surveys on Qualtrics and requested the Production Manager at ECN deactivate the telephone surveys to prevent any additional participants from completing the survey. 
The researcher also requested that Douglas County and Palm Coast remove any information regarding the survey from their website to prevent additional participation.

Sample population report information. At the conclusion of the 2 -week research period, February 17, 2014 at 11:59 p.m., there were 14 telephone-based surveys recorded and 183 Web-based surveys recorded for Douglas County, IL. There were 1,010 Web-based surveys recorded and 53 telephone-based surveys recorded for Palm Coast, FL. Both participating communities were provided news release templates and distributed to them to their local media to help with recruitment. Anyone 18 or older that lived in either area who saw or read a news report about the survey was able to participate.

Qualtrics reporting indicates 1,010 surveys were started in Palm Coast, FL with 692 surveys completed, or $69 \%$. Survey statistics show that $88.32 \%$ of respondents completed the 25 core questions needed to answer the research questions and hypotheses; however the response rate drops off when the respondent is presented the optional, supplemental questions with $67.43 \%$ completing the initial supplemental question.

In Douglas County, 183 surveys were started and 145 completed, or $79 \%$ of respondents completed the entire survey including the supplemental questions. More than $91 \%$ of survey participants completed the 25 core questions needed to answer the research questions and hypotheses, dropping to $77.5 \%$ of respondents completing the initial supplemental survey question.

Several telephone responses were "test" responses in which the researcher called into the telephone-based surveys to ensure each prompt was up and running, entering in test responses. 
These responses were indicated using the Caller ID that was tracked for every individual who called in to complete the survey. Five telephone responses were recorded as ECN Caller ID and were removed from the Palm Coast telephone dataset. The system did not indicate any data responses for another two respondents and were removed from the dataset, resulting in 28 remaining phone responses. There was an $82 \%$ completion rate for the telephone surveys, with drop-offs seen in the final five demographic questions regarding age, income, race and education.

Six telephone responses were recorded as ECN Caller ID and were removed from the Douglas County telephone dataset. The system did not indicate any data responses for three other responses with duplicate Caller IDs, with the same date and time stamp, and were removed from the dataset, resulting in four remaining phone responses for Douglas County. Of the four remaining responses, $100 \%$ of the respondents completed the entire survey of 25 questions.

Data procedures. The researcher loaded the .sav documents from Palm Coast and Douglas County in the SPSS software. The researcher combined the Douglas County Web-based survey responses with the Douglas County telephone responses by hand coding the telephone responses into the data view tab sav document output in the SPSS software. Similarly, the researcher combined the Palm Coast Web-based survey responses with the Palm Coast telephone responses by hand coding the telephone responses into the data view tab .sav document output in the SPSS software. 
There were several questions that did not contain data for the response because there was both user-missing and system-missing data. User-missing data refers to information not collected because the respondent refused to answer the question or the question did not apply to them. System-missing data refers to no values detected for a particular question. To distinguish between data missing, the researcher chose to define the missing values. For numeric variables, the researcher entered a discrete missing value of 999 and labeled the value as "No Response." For string variables, the researcher entered a discrete missing value of 'NR" and labeled the value as "No Response."

The telephone survey introduction, which included information about the research, the principal investigator and instructions, was approximately two minutes in recorded length before the respondent heard the first survey question. Therefore, those respondents whose call length did not exceed two minutes were removed from the dataset because they abandoned the survey before hearing any questions. There were a total of 19 respondent entries removed from the Palm Coast dataset. Two respondent entries were removed from the Douglas County dataset for abandoning the survey before hearing the first survey question.

Descriptive analysis of data. Predictor or independent variables in the study were the socioeconomic identifiers of education, age, gender, race/ethnicity, income and marital status, whereas the dependent variables were identified as action taken, prior knowledge of storm, prior enrollment in CRWW and how the tornado warning was received. A majority of the questions asked in the telephone and Web-based surveys were yes/no nominal scales, therefore frequency distributions were the most appropriate method to provide a descriptive analysis of the data collected for each community. 
Palm Coast, FL. More than $50 \%$ of residents indicated they knew there was a possibility of tornadoes in Palm Coast on December 14, 2013. When the tornado warning was received, $51.3 \%$ of residents took no action, $40.9 \%$ took shelter in a safe place indoors and $4 \%$ of respondents went to a safe place outside. Most Palm Coast residents, representing $53.2 \%$ of respondents, were warned of the tornado by receiving notification on their cellphone. The second highest method residents received tornado warning was through the television at $44.9 \%$, followed by receiving a warning through a neighbor, friend or family member at $17.5 \%$. Other less noted means that residents received the tornado warning were through desktop computer, laptop or tablet indicated by $13.6 \%$ of respondents. Less than $2 \%$ of respondents indicated they received a tornado warning through an outdoor warning/storm siren. Most of central Florida does not use outdoor warning/storm sirens.

Of participating respondents, $28.7 \%$ indicated their annual individual yearly income was between $\$ 35,000$ and $\$ 54,999$ with $24.1 \%$ of respondents categorizing their annual income between $\$ 15,000$ and $\$ 34,999$. Most Palm Coast residents, representing $25.5 \%$ of the survey sample, categorized their annual yearly household income between $\$ 50,000$ and $\$ 74,999$, followed by a very close second, or $25.2 \%$ of respondents indicating their total household income was higher than $\$ 95,000$ annually.

Demographic information designated as independent variables shows that more than half of the respondents, or 59.2\%, are older than 54 years old. The next largest age group represented was $45-54$, or $16.8 \%$ of respondents. Bachelor's degrees were the highest education level indicated by survey respondents with $31.2 \%$, followed by $27.5 \%$ of respondents indicating they had completed their GED or high school diploma. 
Nearly all survey respondents were white, representing $90.4 \%$ of the sample population. More than half of the respondents were female at $65.8 \%$ and were married at $75.8 \%$.

Douglas County, $\boldsymbol{I} \boldsymbol{L}$. More than $89 \%$ of residents surveyed indicated they knew there was a possibility of tornadoes in Douglas County on November 17, 2013. When the tornado warning was received, $16.6 \%$ of residents took no action, $74.9 \%$ took shelter in a safe place indoors and 3.2\% of respondents went to a safe place outside. Most Douglas County residents, representing $71.8 \%$ of respondents, were warned of the tornado by receiving notification on their television. The second highest method residents received tornado warning was through cellphones at $68.4 \%$, followed by receiving a warning through an outdoor warning/storm siren at 59.3\%. Other less noted means that residents received the tornado warning were through desktop computer, laptop or tablet indicated by $31.6 \%$ of respondents. Less than $31 \%$ of respondents indicated they received a tornado warning through a neighbor, friend or family member.

Of the participating respondents, $29.2 \%$ indicated their annual individual yearly income was between $\$ 35,000$ and $\$ 54,999$ with $26.3 \%$ of respondents categorizing their annual income between $\$ 15,000$ and $\$ 34,999$. Most Douglas County residents, representing $28.1 \%$ of the survey population, categorized their annual yearly household as higher than $\$ 95,000$, with $27.5 \%$ indicating their total household income was between $\$ 50,000$ and $\$ 74,999$.

Demographic information designated as independent variables shows that $35.1 \%$ of respondents categorized their age between 35-44. The next largest age group represented was older than 54 , or $31.6 \%$ of respondents. 
Bachelor's degrees were the highest education level indicated by survey respondents with $31 \%$, followed by $29.2 \%$ of respondents indicating they had completed their GED or high school diploma. Most survey respondents were white, representing $97.7 \%$ of the surveyed sample population. Nearly three quarters of the respondents were female at $70.8 \%$ and were married, at $83 \%$.

Instrument Scales. The optional supplemental questions at the conclusion of the initial first 25 questions on the Web surveys for both Palm Coast, FL and Douglas County, IL asked respondents to indicate their responses using scales. The questions related to future tornado warnings; the devices that were most important for them to receive warnings and how confident they were they would receive a warning at various locations. Chronbach's alpha was run to test the internal consistency of the scales.

Palm Coast, FL. The overall alpha for the six communication devices (landline, mobile, weather radio, television, desktop/laptop/tablet, outdoor warning/storm siren) was .060, which is very low and indicates poor internal consistency among the items. Since alpha is low, the ability to predict scores from one item is impossible. The overall alpha for the confidence to receive future warnings (receive warning in time to be safe, receive warning at home, receive warning at work) was 1.00 , which is very high and indicates strong internal consistency among the three items. This means respondents who tended to select high confidence scores for one variable (general confidence) also tended to select high scores for the other items (work and home); enabling the researcher to predict with a level of accuracy the possible scores for the other two confidence variables. 
Douglas County, IL. The overall alpha for the importance of six communication devices question was even lower than the Palm Coast result when Chronbach's alpha was run in the Douglas County dataset, at -.1 , which is very low and indicates poor internal consistency among the items. Since alpha is low, the ability to predict scores from one item is impossible.

The overall alpha for the confidence to receive future warnings was .82 , which is very high and like the Palm Coast alpha, indicates strong internal consistency among the three items. This means respondents who tended to select high confidence scores for one variable (general confidence) also tended to select high scores for the other items (work and home); enabling the researcher to predict with a level of accuracy the possible scores for the other two confidence variables.

The variables in the study varied depending on the hypothesis measured. The following table provides an overview of the variables measured with their respective items on the survey. 


\begin{tabular}{|c|c|c|c|}
\hline Question/Hypothesis & Independent & Dependent & Items on Survey \\
\hline $\begin{array}{l}\text { What SES and demographic } \\
\text { differences exist in how people } \\
\text { were notified of the tornado? }\end{array}$ & $\begin{array}{l}\text { Demographic } \\
\text { differences: } \\
\text { location type, } \\
\text { age, } \\
\text { race/ethnicity, } \\
\text { marital status, } \\
\text { how warnings } \\
\text { were received }\end{array}$ & $\begin{array}{l}\text { SES } \\
\text { differences: } \\
\text { Income, } \\
\text { education }\end{array}$ & $\begin{array}{l}\text { Category selection } \\
\text { of socioeconomic } \\
\text { and demographic } \\
\text { indicators, nominal } \\
\text { responses to } \\
\text { receiving } \\
\text { notification on } \\
\text { devices }\end{array}$ \\
\hline $\begin{array}{l}\text { Citizens of a higher SES will have } \\
\text { known about a possible tornado } \\
\text { threat prior to when the tornado hit } \\
\text { more than those of a lower SES. }\end{array}$ & $\begin{array}{l}\text { Prior } \\
\text { knowledge of } \\
\text { tornado }\end{array}$ & $\begin{array}{l}\text { Income, } \\
\text { education }\end{array}$ & $\begin{array}{l}\text { Category selection } \\
\text { of income and } \\
\text { education, nominal } \\
\text { response to prior } \\
\text { knowledge }\end{array}$ \\
\hline $\begin{array}{l}\text { Citizens of a higher SES will have } \\
\text { received emergency tornado } \\
\text { warnings on more communication } \\
\text { devices than those of a lower SES. }\end{array}$ & $\begin{array}{l}\text { Devices used } \\
\text { to receive } \\
\text { warning }\end{array}$ & $\begin{array}{l}\text { Income, } \\
\text { education }\end{array}$ & $\begin{array}{l}\text { Category selection } \\
\text { of income and } \\
\text { education, nominal } \\
\text { responses to how } \\
\text { warnings were } \\
\text { received }\end{array}$ \\
\hline $\begin{array}{l}\text { Citizens of a higher SES were more } \\
\text { likely to be enrolled to receive } \\
\text { tornado notifications through } \\
\text { CRWW than those of a lower SES. }\end{array}$ & $\begin{array}{l}\text { Prior } \\
\text { enrollment in } \\
\text { CRWW }\end{array}$ & $\begin{array}{l}\text { Income, } \\
\text { education } \\
\text { Supplemental: } \\
\text { Age and } \\
\text { gender }\end{array}$ & $\begin{array}{l}\text { Category selection } \\
\text { of income and } \\
\text { education, nominal } \\
\text { response to } \\
\text { enrollment in } \\
\text { CRWW }\end{array}$ \\
\hline $\begin{array}{l}\text { Citizens who were enrolled in } \\
\text { CRWW prior to the storm were } \\
\text { more confident to receive future } \\
\text { warnings than those who had not } \\
\text { enrolled prior. }\end{array}$ & $\begin{array}{l}\text { Prior } \\
\text { enrollment in } \\
\text { CRWW }\end{array}$ & $\begin{array}{l}\text { Confidence } \\
\text { level }\end{array}$ & $\begin{array}{l}\text { Nominal response } \\
\text { to enrollment in } \\
\text { CRWW, interval } \\
\text { response to } \\
\text { confidence level }\end{array}$ \\
\hline $\begin{array}{l}\text { Citizens of a higher SES were more } \\
\text { likely to take action to relocate to a } \\
\text { safe place after receiving the } \\
\text { emergency tornado alert more than } \\
\text { those of lower SES. }\end{array}$ & Action taken & $\begin{array}{l}\text { Income, } \\
\text { education }\end{array}$ & $\begin{array}{l}\text { Category selection } \\
\text { of income and } \\
\text { education, category } \\
\text { selection of action } \\
\text { taken }\end{array}$ \\
\hline
\end{tabular}




\section{Results}

\section{Statistical Tests}

The criterion for choosing select statistical tests was completed based on the nature of the question and the type of score. The major inferential research question, what SES and demographic differences existed in the surveyed sample population's receipt of an emergency tornado warning on various communication devices, is a group comparison question containing categorical or nominal variables to measure identity and difference. A cross-tabulation analysis was determined to be the best way to analyze categorical data to determine the relationship between the variables. Chi-squares were the primary statistic used for testing the statistical significance of the cross-tabulation tables.

\section{Method of receiving warnings.}

Palm Coast, $\boldsymbol{F L}$. The first cross-tabulation was done to determine the relationship between age and the types of devices that the tornado warnings were received. $\mathrm{P}<.001$, which means that the variables received a warning on a landline and age are in fact related. See Table 1 on the following page for a crosstabulation analysis of the variables age tested against the receipt of the tornado warning through a landline telephone. 


\begin{tabular}{|l|l|l|l|l|l|}
\hline \multicolumn{7}{|c|}{$\begin{array}{c}\text { Palm Coast Crosstabulation Analysis of Age vs. } \\
\text { Receipt of Warning via Landline }\end{array}$} \\
\hline Age Group \\
\hline Received warning on landline & $18-24$ & $25-34$ & $35-44$ & $45-54$ & $\begin{array}{l}\text { Older } \\
\text { than } 54\end{array}$ \\
\hline $\begin{array}{l}\text { Yes } \\
\% \text { within age group count }\end{array}$ & 0 & 5 & 20 & 35 & 248 \\
\hline $\begin{array}{l}\text { No } \\
\% \text { within age group count }\end{array}$ & 12 & $7.1 \%$ & $14.4 \%$ & $22.6 \%$ & $45.5 \%$ \\
\hline $\begin{array}{l}\text { Pearson Chi-Square .00 } \\
\text { Asymp. Sig (2-sided) }\end{array}$ & $100 \%$ & $92.9 \%$ & $85.6 \%$ & $77.4 \%$ & 297 \\
\hline
\end{tabular}

Table 1

Of Palm Coast respondents who received a warning on a landline, $33.8 \%$ of respondents designated their location type as suburban. However, $66 \%$ of the sample population in Palm Coast did not receive a warning through a landline. This means that in Palm Coast, more people who live in the suburbs are likely to receive warning on a landline. A Chisquare test did not find a relationship between the variables received warning on a landline and location type, with a significance value well over 0.05 .

Nearly $92 \%$ of respondents who indicated they received a tornado warning on a cellphone were between the ages of $18-24$, compared to $47.7 \%$ of respondents between the ages of 45-54, indicating the youngest respondent group is more likely to receive warnings on a cellphone. More than half of the respondents between the ages of 45 and 54 said they did not receive a warning on a cellphone, compared to $46.2 \%$ of respondents older than 54, meaning people between the ages of 45 and 54 are more likely not to receive a warning on a cellphone compared to those older than 54. Since the significance factor is 0.04 , the researcher can conclude that there is a relationship between receiving a tornado warning on a cellphone and age. See Table 2 on the following page. 


\begin{tabular}{|c|c|c|c|c|c|}
\hline \multicolumn{6}{|c|}{$\begin{array}{l}\text { Palm Coast Crosstabulation Analysis of Age vs. } \\
\text { Receipt of Warning via Cellphone }\end{array}$} \\
\hline \multicolumn{6}{|c|}{ Age Group } \\
\hline Received warning on landline & $18-24$ & $25-34$ & $35-44$ & $45-54$ & $\begin{array}{l}\text { Older } \\
\text { than } 54\end{array}$ \\
\hline $\begin{array}{l}\text { Yes } \\
\% \text { within age group count }\end{array}$ & $\begin{array}{l}11 \\
91.7 \%\end{array}$ & $\begin{array}{l}41 \\
58.6 \%\end{array}$ & $\begin{array}{l}78 \\
56.1 \%\end{array}$ & $\begin{array}{l}74 \\
47.7 \%\end{array}$ & $\begin{array}{l}293 \\
53.8 \%\end{array}$ \\
\hline $\begin{array}{l}\text { No } \\
\% \text { within age group count }\end{array}$ & $\begin{array}{l}1 \\
8.3 \%\end{array}$ & $\begin{array}{l}29 \\
41.4 \%\end{array}$ & $\begin{array}{l}61 \\
43.9 \%\end{array}$ & $\begin{array}{l}81 \\
52.3 \%\end{array}$ & $\begin{array}{l}252 \\
46.2 \%\end{array}$ \\
\hline $\begin{array}{l}\text { son Chi-Square .04 } \\
\text { mp. Sig (2-sided) }\end{array}$ & & & & & \\
\hline
\end{tabular}

Table 2

Of respondents who received warning through a cellphone, $15.9 \%$ indicated their location type as rural. In Palm Coast, those who receive warning through a cellphone are more likely to live in a rural location. A Chi-square test did not find a relationship between the variables received warning on a cellphone and location type, with a significance value of .329 .

More than half of survey respondents older than 54 in Palm Coast received warning of the December 14, 2013 tornado through the television, whereas $58.3 \%$ of respondents age 18-24 did not receive a warning through the television. This means those older than 54 are more likely to receive a warning through the TV than young adults. $\mathrm{P}<.001$, which means that the variables received a warning through the television and age are in fact related. See Table 3 on the following page for the analysis of the variables age and the receipt of a warning through the TV. 


\begin{tabular}{|c|c|c|c|c|c|}
\hline \multicolumn{6}{|c|}{ Palm Coast Crosstabulation Analysis of Age vs. Receipt of Warning via TV } \\
\hline \multicolumn{6}{|c|}{ Age Group } \\
\hline Received warning on landline & $18-24$ & $25-34$ & $35-44$ & $45-54$ & $\begin{array}{l}\text { Older } \\
\text { than } 54\end{array}$ \\
\hline $\begin{array}{l}\text { Yes } \\
\% \text { within age group count }\end{array}$ & $\begin{array}{l}5 \\
41.7 \%\end{array}$ & $\begin{array}{l}24 \\
34.3 \%\end{array}$ & $\begin{array}{l}38 \\
27.3 \%\end{array}$ & $\begin{array}{l}59 \\
38.1 \%\end{array}$ & $\begin{array}{l}286 \\
52.5 \%\end{array}$ \\
\hline $\begin{array}{l}\text { No } \\
\% \text { within age group count }\end{array}$ & $\begin{array}{l}7 \\
58.3 \%\end{array}$ & $\begin{array}{l}46 \\
65.7 \%\end{array}$ & $\begin{array}{l}101 \\
72.7 \%\end{array}$ & $\begin{array}{l}96 \\
61.9 \%\end{array}$ & $\begin{array}{l}259 \\
47.5 \%\end{array}$ \\
\hline $\begin{array}{l}\text { Pearson Chi-Square .00 } \\
\text { Asymp. Sig (2-sided) }\end{array}$ & & & & & \\
\hline
\end{tabular}

Table 3

More than $80 \%$ of Palm Coast respondents who received a warning through the TV indicated their location type as suburban whereas $16 \%$ noted their location was rural. Those who receive tornado warnings through the TV are more likely to live in a suburban location. There was no association found between receipt of a warning through the TV and location type, with a .327 significance value found in a Chi-square test.

In Palm Coast, $86 \%$ of the surveyed population said they did not receive a tornado warning on a desktop computer, laptop or tablet. Of those who did receive warnings this way, adults aged $18-24$ were most likely to receive warnings at $25 \%$, followed by those older than 54 at $15.6 \%$. A Chi-square test does not indicate any relationship between the variables of receiving a warning on a desktop computer, laptop or tablet and age in Palm Coast, with the significance factor well over 0.05 . Of respondents who received warnings through a desktop computer, laptop or tablet, $89.9 \%$ indicated their location type as suburban. Residents in a suburban area are more likely to receive a tornado warning through a desktop computer, laptop or tablet compared to those in rural areas. 
A Chi-square test value of .086 indicates there is no relation to location type and receiving warnings this way.

There are no outdoor warning or storm sirens in central Florida and none specifically in Palm Coast, FL. This was conveyed as $97.5 \%$ of the sample population indicating they did not receive warning of the December 14, 2013 tornado through a siren. Data analysis of age and location variables are not appropriate for testing against sirens because outdoor warning/storm sirens are not used in Palm Coast.

In Palm Coast, $82 \%$ of survey respondents indicated they did not receive warning of the December 14, 2013 tornado from a neighbor, friend or family member. Of those who did, $41.7 \%$ were between the ages of $18-24$ whereas $12.3 \%$ were older than 54 . This means the age group 18-24 is more likely to receive a warning from a friend, neighbor or family member than any other group. Since $\mathrm{p}<0.05$, the researcher can conclude there is a relationship between receiving a warning from a neighbor, friend or family member and age.

\begin{tabular}{|c|c|c|c|c|c|}
\hline \multicolumn{6}{|c|}{$\begin{array}{c}\text { Palm Coast Crosstabulation Analysis of Age vs. Receipt of Warning } \\
\text { via Friend, Neighbor or Family Member }\end{array}$} \\
\hline \multicolumn{6}{|c|}{ Age Group } \\
\hline Received warning on landline & $18-24$ & $25-34$ & $35-44$ & $45-54$ & $\begin{array}{l}\text { Older } \\
\text { than } 54\end{array}$ \\
\hline $\begin{array}{l}\text { Yes } \\
\% \text { within age group count }\end{array}$ & $\begin{array}{ll}5 \\
41.7 \% \\
\end{array}$ & $\begin{array}{l}27 \\
38.6 \%\end{array}$ & $\begin{array}{l}34 \\
24.5 \%\end{array}$ & $\begin{array}{l}33 \\
21.3 \%\end{array}$ & $\begin{array}{l}67 \\
12.3 \%\end{array}$ \\
\hline $\begin{array}{l}\text { No } \\
\% \text { within age group count }\end{array}$ & $\begin{array}{l}7 \\
58.3 \%\end{array}$ & $\begin{array}{l}43 \\
61.4 \%\end{array}$ & $\begin{array}{l}105 \\
75.5 \%\end{array}$ & $\begin{array}{l}122 \\
78.7 \%\end{array}$ & $\begin{array}{l}478 \\
87.7 \%\end{array}$ \\
\hline $\begin{array}{l}\text { Pearson Chi-Square .00 } \\
\text { Asymp. Sig (2-sided) }\end{array}$ & & & & & \\
\hline
\end{tabular}

Table 4 
Of those who received warning from a neighbor, friend or family member, $83.7 \%$ of respondents indicated they lived in a suburban area. Residents in suburban areas are more likely to receive warning from a neighbor, friend or family member in Palm Coast. A Chi-square test did not find any association between this method of warning and location type, with a significance value of .721 .

Douglas County, IL. While $38.9 \%$ of respondents older than 54 received a tornado warning on a landline, $22.2 \%$ of respondents ages $18-24$ said they received a warning the same way, indicating that those over the age of 54 are more likely to receive tornado warnings through a landline telephone than those between the ages of 18-24. While $88.2 \%$ of respondents between $25-34$ did not receive a warning through a landline, $87.1 \%$ of respondents $45-54$ did not receive a warning through a landline, indicating that those 25-34 are slightly more likely to not receive tornado warnings through a landline telephone. Since the significance value is .01 , the results conclude that there is a relationship between the variables received a warning on a landline and age for the Douglas County sample population.

\begin{tabular}{|l|l|l|l|l|l|}
\hline \multicolumn{7}{|c|}{$\begin{array}{c}\text { Douglas County Crosstabulation Analysis of Age vs. } \\
\text { Receipt of Warning via Landline }\end{array}$} \\
\hline \multicolumn{7}{|c|}{ Age Group } \\
\hline Received warning on landline & $18-24$ & $25-34$ & $35-44$ & $45-54$ & $\begin{array}{l}\text { Older } \\
\text { than 54 }\end{array}$ \\
\hline $\begin{array}{l}\text { Yes } \\
\% \text { within age group count }\end{array}$ & $22.2 \%$ & $11.8 \%$ & $13.3 \%$ & $12.9 \%$ & $38.9 \%$ \\
\hline $\begin{array}{l}\text { No } \\
\% \text { within age group count }\end{array}$ & $77.8 \%$ & $\begin{array}{l}15 \\
88.2 \%\end{array}$ & $\begin{array}{l}52 \\
86.7 \%\end{array}$ & $\begin{array}{l}27 \\
71.1 \%\end{array}$ & $\begin{array}{l}33 \\
61.1 \%\end{array}$ \\
\hline $\begin{array}{l}\text { Pearson Chi-Square .01 } \\
\text { Asymp. Sig (2-sided) }\end{array}$ \\
Table 5
\end{tabular}


Most of Douglas County respondents indicated their location type as rural. Of those respondents, $81.6 \%$ did not receive a warning on a landline telephone. Of those who received a warning on a landline telephone, $18.4 \%$ of respondents lived in a rural location. Of those who received a warning through a landline, the numbers are almost evenly split for those who lived in rural or suburban locations. A Chi-square test did not reveal any relationship between location type and the receipt of a tornado warning through a landline telephone, with a significance value of .15.

More than $78 \%$ of respondents who indicated they received a tornado warning on a cellphone were between the ages of $35-44$, compared to $58.1 \%$ of respondents between the ages of 45-54, indicating those between the ages of 35-44 are more likely to receive warnings on a cellphone. A little more than $30 \%$ of the surveyed Douglas County population indicated they did not receive a warning on a cellphone, compared to $41.9 \%$ of respondents between 45-54 indicating they did not receive a warning on a cellphone.

The significance value is .28 , and the researcher can conclude that there is not a relationship between the receipt of a tornado warning by cellphone and age in Douglas County. A majority of respondents, or $67.8 \%$, indicated they received warning of the tornado on a cellphone. Of those who received warning this method, $70.9 \%$ indicated their location type as rural. This means that those who live in rural areas were more likely to have received warning on a cellphone. After a Chi-square test was completed, the significance value was .19 , indicating there is no relationship between the variables received a warning on a cellphone and location type. 
Nearly $80 \%$ of survey respondents older than 54 received warning on a TV, compared to $66.7 \%$ of respondents $18-24$ receiving a warning through the TV. This means those older than 54 are more likely to receive a tornado warning through the television than all other age groups surveyed. The significance value is .40, well more than 0.05 , and the researcher can conclude that there is not a relationship between the receipt of a tornado warning by television and age in Douglas County.

More than $70 \%$ of respondents indicated they received warning of the impending tornado on TV. Of those who received a warning through the TV, 74 people indicated their location type as rural, meaning of those who received a warning this way, it is more likely their location type was rural. The significance level was. 48 meaning there is not find a relationship between the two variables location type and received warning through a television.

In Douglas County, $69 \%$ of the surveyed population indicated they did not receive a tornado warning on a desktop computer, laptop or tablet. Of those that did, the largest age group who received a warning through a desktop computer, laptop or tablet was 1824. Of those who did not receive a warning this method, the largest age group was 25-34. Since the significance factor is .01 , the researcher can conclude that there is a relationship between receiving a tornado warning on a desktop computer, laptop or tablet and age. See Table 6 on the following page for the analysis of the variables age and the receipt of the tornado warning on a desktop computer, laptop or tablet. 


\begin{tabular}{|c|c|c|c|c|c|}
\hline \multicolumn{6}{|c|}{$\begin{array}{l}\text { Douglas County Crosstabulation Analysis of Age vs. } \\
\text { Receipt of Warning via Desktop computer, laptop or tablet }\end{array}$} \\
\hline \multicolumn{6}{|c|}{ Age Group } \\
\hline Received warning on landline & $18-24$ & $25-34$ & $35-44$ & $45-54$ & $\begin{array}{l}\text { Older } \\
\text { than } 54\end{array}$ \\
\hline $\begin{array}{l}\text { Yes } \\
\% \text { within age group count }\end{array}$ & $\begin{array}{l}5 \\
55.6 \%\end{array}$ & $\begin{array}{l}1 \\
5.9 \%\end{array}$ & $\begin{array}{ll}20 \\
33.3 \%\end{array}$ & $\begin{array}{l}5 \\
16.1 \%\end{array}$ & $\begin{array}{l}22 \\
40.7 \%\end{array}$ \\
\hline $\begin{array}{l}\text { No } \\
\% \text { within age group count }\end{array}$ & $\begin{array}{l}4 \\
44.4 \%\end{array}$ & $\begin{array}{l}16 \\
94.1 \%\end{array}$ & $\begin{array}{l}40 \\
66.7 \%\end{array}$ & $\begin{array}{l}26 \\
83.9 \%\end{array}$ & $\begin{array}{l}32 \\
59.3 \%\end{array}$ \\
\hline $\begin{array}{l}\text { Chi-Square } .01 \\
\text { Sig (2-sided) }\end{array}$ & & & & & \\
\hline
\end{tabular}

Table 6

Of those who did not receive a warning on a desktop computer, laptop or tablet, $72 \%$ designated their location type as suburban. This means those with suburban location types are less likely to receive tornado warnings through a desktop computer, laptop or tablet device. After a Chi-square test was completed, there was no relationship found between the variables received warning through a desktop computer, laptop or tablet device and location type.

In Douglas County, $65 \%$ of respondents who indicated they received a warning through an outdoor warning/storm siren were between the ages of 35 and 44, with $48.1 \%$ of those older than 54 indicating they received a warning through a siren. Of those who did not receive a warning through a siren, the majority was older than 54 , or $51.9 \%$. The significance value is .25 , and the researcher can conclude that there is not a relationship between the receipt of a tornado warning by an outdoor warning/storm siren and age in Douglas County.

More than $60 \%$ of Douglas County survey respondents received a warning through an outdoor warning/storm siren. Of those, most were from rural location types. 
This means that of those who received a warning through an outdoor warning/storm siren, it is more likely their location type was rural. With a significance value of .01, a Chi-square test revealed there is a relationship between location type and the receipt of a tornado warning through an outdoor warning/storm siren.

\begin{tabular}{|l|l|l|}
\hline \multicolumn{4}{|c|}{$\begin{array}{c}\text { Douglas County Crosstabulation Analysis of Location Type vs. } \\
\text { Receipt of Warning via Outdoor Warning/Storm Siren }\end{array}$} \\
\hline \multicolumn{3}{|c|}{ Location Type } \\
\hline Received warning through outdoor warning/storm siren & \multicolumn{1}{|c|}{ Rural } & Suburban \\
\hline Yes & 54 & 49 \\
$\%$ within location type & $52.4 \%$ & $72.1 \%$ \\
\hline No & 49 & 19 \\
$\%$ within location type & $47.6 \%$ & $27.9 \%$ \\
\hline Pearson Chi-Square .01 & & \\
Asymp. Sig (2-sided) & & \\
\hline Table 7
\end{tabular}

Nearly $70 \%$ of respondents did not receive warning of the November 17, 2013 from a neighbor, friend or family member. Of those that did, $66.7 \%$ were between the ages of 18 and 24, whereas those older than 54 represented $20.4 \%$ of those who received the warning in the same method. This means those between the ages of 18 and 24 are the most likely to receive warning from a neighbor, friend or family member. A Chi-square test shows a relationship between the variables age and received a warning from a neighbor, friend or family member. See Table 8 on the following page for the analysis of the age variable tested against the receipt of a warning through word of mouth. 


\begin{tabular}{|c|c|c|c|c|c|}
\hline \multicolumn{6}{|c|}{$\begin{array}{l}\text { Douglas County Crosstabulation Analysis of Age vs. } \\
\text { Receipt of Warning via Neighbor, Friend or Family Member }\end{array}$} \\
\hline \multicolumn{6}{|c|}{ Age Group } \\
\hline Received warning on landline & $18-24$ & $25-34$ & $35-44$ & $45-54$ & $\begin{array}{l}\text { Older } \\
\text { than } 54\end{array}$ \\
\hline $\begin{array}{l}\text { Yes } \\
\% \text { within age group count }\end{array}$ & $\begin{array}{l}6 \\
66.7 \%\end{array}$ & $\begin{array}{l}10 \\
58.8 \%\end{array}$ & $\begin{array}{l}17 \\
28.3 \%\end{array}$ & $\begin{array}{l}8 \\
25.8 \%\end{array}$ & $\begin{array}{l}11 \\
20.4 \%\end{array}$ \\
\hline $\begin{array}{l}\text { No } \\
\% \text { within age group count }\end{array}$ & $\begin{array}{l}3 \\
33.3 \%\end{array}$ & $\begin{array}{l}7 \\
41.2 \%\end{array}$ & $\begin{array}{l}43 \\
71.7 \%\end{array}$ & $\begin{array}{l}23 \\
74.2 \%\end{array}$ & $\begin{array}{l}43 \\
79.6 \%\end{array}$ \\
\hline $\begin{array}{l}\text { Pearson Chi-Square } .01 \\
\text { Asymp. Sig (2-sided) }\end{array}$ & & & & & \\
\hline
\end{tabular}

Of those who received a warning from a friend, neighbor or family member, most respondents indicated their location type as rural, meaning it is more likely those living in rural areas would receive a warning from a neighbor, friend or family member. A relationship exists between the variables received warning from a neighbor, friend or family member and location type, with $\mathrm{p}<.05$.

\begin{tabular}{|l|l|l|}
\hline \multicolumn{3}{|c|}{$\begin{array}{l}\text { Douglas County Crosstabulation Analysis of Location Type vs. } \\
\text { Receipt of Warning via Neighbor, Friend or Family Member }\end{array}$} \\
\hline & \multicolumn{2}{|c|}{ Location } \\
\hline Type & \multicolumn{2}{|c|}{ Rural } \\
\hline Received word of mouth warning & 40 & 12 \\
\hline Yes & $38.8 \%$ & $72.1 \%$ \\
$\%$ within location type & 63 & 56 \\
\hline No & $61.2 \%$ & $82.4 \%$ \\
$\%$ within location type & & \\
\hline Pearson Chi-Square .00 & & \\
Asymp. Sig (2-sided) & \\
\hline
\end{tabular}




\section{H1: Citizens of a higher SES will have known about a possible tornado threat prior to}

when the tornado hit more than those of a lower SES. Education and total household

income were entered as continuous variables in the regression model as separate

variables. This allowed the researcher to determine if one variable compared to the other

was significant, instead of combining the variables for less hypothesis support. Binary

logistic regressions were completed to predict the categorical, dichotomous variable from

predictor variables. The dichotomous variable in the regression was prior knowledge,

coded as 1 (had prior knowledge) and 0 (no prior knowledge). The predictor variables

were education and total household income. Single models were run for each

demographic.

Palm Coast, FL. A Chi-square of .312 indicates adding income did not significantly predict the respondent's prior knowledge of storms that day. The researcher fails to reject a null hypothesis. Respondents of a higher socioeconomic level as it pertains to total household income compared to those of a lower SES did not have more prior knowledge of the tornado in Palm Coast that day.

The variable education was then tested against prior knowledge. The Omnibus Tests of Model Coefficients gave a Chi-square of .337, not significant higher than 0.05. The researcher fails to reject a null hypothesis; adding the education variable to the model did not significantly increase the respondent's prior knowledge of storms that day.

Though not formally part of the hypotheses, regression models were also completed to test other predictor variables of gender and age related to prior knowledge of the storm. 
$\mathrm{P}<.05$, indicating older age is associated with prior knowledge of the tornado. The older a respondent, the more likely they had prior knowledge of storms in their area that day.

When gender was tested against prior knowledge, a p-value of .070 was found. Gender does not appear to be associated with the respondent's prior knowledge of storms in their area. The Knowledge Gap and Structuration theories related to this analysis are not founded; in this study, women did not have more prior knowledge of the storm than men as indicated in previous theory studies and the college educated do not appear to acquire more knowledge than those who are less educated.

Douglas County, IL. A p-value of .03 led the researcher to reject the null hypotheses. As it relates to total household income and unlike the Palm Coast regression, the higher the income, the higher the likelihood of a person knowing there was a possibility of storms in their area that day. In Douglas County, the Structuration Theory specifically aligns with these findings; respondents with more resources were able to achieve their desired ends (knowledge) more easily and ultimately be more informed.

When education was tested against prior knowledge, there was no significance found. The researcher fails to reject a null hypothesis; adding the education variable to the model did not significantly increase the respondent's prior knowledge of storms that day. More education was not a factor in the respondent's prior knowledge of storms on November 17, 2013. The Knowledge Gap theory is unfounded in this study; the college educated did not acquire more knowledge compared to the less educated. 
To compare additional findings with Palm Coast, regression models were also completed to test other predictor variables of gender and age related to prior knowledge of the storm. A significance value of .122 (p>.05) was found, indicating that older age is not associated with prior knowledge of the tornado.

When gender was tested against prior knowledge, a p-value of .090 was found. Gender does not appear to be associated with the respondent's prior knowledge of storms in their area. The Knowledge Gap and Structuration theories related to this analysis are not founded; in this study, women did not have more prior knowledge of the storm than men as indicated in previous theory studies and the college educated does not appear to acquire more knowledge than those who are less educated.

\section{H2: Citizens of a higher SES will have received emergency tornado warnings on more communication devices than those of a lower SES.}

A linear regression was selected to determine the statistical relationship between the predictor values total household income and education against the response variable, receipt of a tornado warning on a specific communication device. A linear regression was completed on each of the six individual devices in which respondents received a tornado warning.

Palm Coast, $\boldsymbol{F L}$. Non-significant p-values of .595 for annual household income and .767 for education level suggests that changes in education and income are not associated with changes in the respondent's receipt of a tornado warning through a landline. The researcher fails to reject a null hypothesis. 
When SES was tested against the receipt of a warning on a cellphone, nonsignificant p-values were found for annual household income (.064) and education level (.649). The researcher fails to reject a null hypothesis; changes in the predictor variables are not associated with changes in the response.

There was no association with a respondent's receipt of tornado warning through the TV and SES, with p-values for both education and household income well above .05. researcher fails to reject a null hypothesis. Higher SES does not mean survey respondents received more warning through the TV than lower SES respondents.

When SES was tested against receipt of a warning on a desktop computer, laptop or tablet, no associations was found between SES and annual household income with a pvalue at .51 . However, a p-value of .05 indicates there is an association between receiving a warning through a desktop computer, laptop or tablet and education level.

\begin{tabular}{|l|l|l|l|l|l|}
\hline \multicolumn{6}{|c|}{ Palm Coast Linear Regression of Education \& Income vs. } \\
Receipt of Warning on Desktop Computer, Laptop or Tablet as the Dependent \\
Variable
\end{tabular}


The researcher fails to reject a null hypothesis as it relates to receipt of a tornado warning through an outdoor warning/storm siren. Large, non-significant p-values of .48 for annual household income and .16 for education level do not suggest a relationship between SES and receiving a warning through a tornado siren.

P-values of more than .68 for both SES indicators of income and education were found when tested against receiving a warning from a neighbor, friend or family member. The researcher fails to reject a null hypothesis; the higher the SES level does not mean the higher inclination to receive warnings in this method.

These findings do not provide support for the Diffusion of Innovations, Knowledge Gap or Structuration theories. They do not help explain if respondents of a higher SES benefit more than those of a lower SES in acquiring knowledge of the storm through various communication devices.

Douglas County, IL. A low p-value of .02 for annual household income and landline allowed the researcher to reject the null hypothesis. Annual household income was found to be meaningful as it relates to a respondent's receipt of a tornado warning on a landline telephone. See Table 11 on the following page for an analysis of education and income tested against the variable received a warning on a landline. 


\begin{tabular}{|c|c|c|c|c|c|}
\hline \multicolumn{6}{|c|}{$\begin{array}{l}\text { Douglas County Linear Regression of Education \& Income vs. Receipt of } \\
\text { Warning on Landline as the Dependent Variable }\end{array}$} \\
\hline Model & $\begin{array}{l}\text { Unstar } \\
\text { Coeffi }\end{array}$ & $\begin{array}{l}\text { dardized } \\
\text { ients }\end{array}$ & $\begin{array}{l}\text { Standardized } \\
\text { Coefficients }\end{array}$ & $\mathrm{t}$ & Sig. \\
\hline \multirow[b]{2}{*}{ (Constant) } & B & $\begin{array}{l}\text { Std. } \\
\text { Error }\end{array}$ & Beta & \multirow[b]{2}{*}{137.33} & \multirow[b]{2}{*}{.00} \\
\hline & 14.82 & .11 & & & \\
\hline Annual Household Income & -.06 & .03 & -.2 & -2.44 & .02 \\
\hline Education Level & .05 & .03 & .15 & 1.83 & .07 \\
\hline
\end{tabular}

Table 11

Conversely, a larger, non-significant p-value of .07 for education suggests that changes in education are not associated with changes in the respondent's receipt of a tornado warning through a landline. The researcher fails to reject a null hypothesis.

P-values of .383 for annual household income and .843 for education level are non-significant when tested against receipt of a tornado warning on a cellphone. Results indicate that changes in education and household income are not associated with a respondent's receipt of a tornado warning on a cellphone. The researcher fails to reject a null hypothesis.

Non-significant p-values of .09 for annual household income and .30 for education level were found when tested against received warning on TV. The researcher can assume that changes in education level and annual household income are not associated with receiving a tornado warning on a TV. The researcher fails to reject a null hypothesis. 
When SES as it relates to household income and education was tested against receiving a warning on a desktop, laptop or tablet device, non-significant p-values were found for both independent variables. With a p-value of .84 for household income and .11 for education, the researcher suggests higher levels of household income and education are not associated with receiving a warning on a TV. The researcher fails to reject a null hypothesis.

A low p-value of .03 for household income was found when tested against receiving a warning through an outdoor warning/storm siren. The researcher rejects the null hypothesis; changes in total household income are related to changes in receiving a warning through an outdoor warning/storm siren. Higher income is associated with receiving a warning through an outdoor warning/storm siren.

\begin{tabular}{|l|l|l|l|l|l|}
\hline \multicolumn{6}{|c|}{$\begin{array}{l}\text { Douglas County Linear Regression of Education \& Income vs. Receipt of } \\
\text { Warning through Outdoor Warning/Storm Siren as the Dependent Variable }\end{array}$} \\
\hline Model & $\begin{array}{l}\text { Unstandardized } \\
\text { Coefficients }\end{array}$ & $\begin{array}{l}\text { Standardized } \\
\text { Coefficients }\end{array}$ & $\mathrm{t}$ & Sig. \\
\hline & $\mathrm{B}$ & $\begin{array}{l}\text { Std. } \\
\text { Error }\end{array}$ & Beta & & \\
\cline { 2 - 6 } (Constant) & 1.33 & .13 & & 10.38 & .00 \\
Annual Household Income & .07 & .03 & .19 & 2.39 & .03 \\
Education Level & -.06 & .04 & -.13 & -1.63 & .11 \\
\hline
\end{tabular}


P-values above .05 were found for annual household income and education level when tested against receiving a warning from a neighbor, friend or family member. The researcher fails to reject a null hypothesis; there is not an association between high and low SES and receiving a warning through a neighbor, friend or family member.

Theory support in this analysis was inconclusive. Though a combination of Diffusion of Innovations, Knowledge Gap and Structuration theories help explain that those of a higher SES are able to associate more with receiving warnings through a landline telephone and tornado siren, they do not help explain if and how SES associates with the other devices in which respondents received warning.

\section{H2a: Citizens of a higher SES were more likely to have enrolled to receive emergency tornado notifications through their County's CodeRED Weather} Warning service than those of a lower SES. Education and total household income were entered as continuous variables in the model as separate variables. This allowed the researcher to determine if one variable over another was significant, instead of combining the variables for less hypothesis support.

Palm Coast, FL. A binary logistic regression was completed and a Chi-square of .13 was not significant higher than 0.05 . The researcher fails to reject a null hypothesis; adding the total household income variable to the model did not significantly increase the respondent's enrollment in CRWW prior to the storm. Respondents of a higher socioeconomic level as it pertains to total household income were not enrolled to receive CRWW notifications more than those of a lower SES. 
To determine the categorical variable, prior enrollment in CRWW as it relates to education, a binary logistic regression was completed. A Chi-square of 2.80 was not significant higher than 0.05 . The researcher fails to reject a null hypothesis; adding the education variable to the model did not significantly increase the respondent's enrollment in CRWW prior to the storm. Respondents of a higher socioeconomic level as it pertains to the highest level of education completed were not enrolled to receive CRWW notifications more than those of a lower SES.

Though not formally part of the hypotheses, regression models were also completed to test other predictor variables of gender and age related to prior enrollment in CodeRED Weather Warning before the tornado hit. $\mathrm{P}<.05$, meaning older age is associated with prior enrollment in CodeRED Weather Warning. The older a respondent, the more likely they were to have enrolled to receive notifications through the CodeRED Weather Warning service.

When gender was tested against prior enrollment, a p-value of .16 was found. Gender does not appear to be associated with the respondent's prior enrollment in CodeRED Weather Warning. The Knowledge Gap and Structuration theories related to this analysis are not founded; in this study, women did not have more prior knowledge of the storm than men as indicated in previous theory studies and the college educated do not appear to acquire more knowledge than those who are less educated. 
In Palm Coast, the Diffusion of Innovations and Structuration theories related to this analysis are not justified. Findings suggest otherwise; in this study, respondents with more education and higher household income were not more likely to have enrolled in CRWW prior to the storm than those who were less educated with lower household income totals.

Douglas County, IL. A binary logistic regression was completed with a p-value of .77, not significant higher than 0.05 . The researcher fails to reject a null hypothesis; adding the total household income variable to the model did not significantly increase the respondent's enrollment in CRWW prior to the storm. Respondents of a higher socioeconomic level as it pertains to total household income were not enrolled to receive CRWW notifications more than those of a lower SES.

The Diffusion of Innovations and Structuration theories related to this analysis are not founded; in this study, those of a higher SES, or with "more resources" did not adopt the CRWW technology and were not more likely to be enrolled to receive CRWW notifications compared to a lower SES, an action that would help to keep them informed.

To determine the categorical variable, prior enrollment in CRWW as it relates to total household income and education, a binary logistic regression was completed. A p-value of .72 indicated no significance. The researcher fails to reject a null hypothesis; adding the education variable to the model did not significantly increase the respondent's enrollment in CRWW prior to the storm. Respondents of a higher socioeconomic level as it pertains to the highest level of education completed were not enrolled to receive CRWW notifications more than those of a lower SES. 
The Knowledge Gap theory related to this analysis is not founded; in this study, respondents with higher education did not have more prior knowledge of the storm than those with less education as indicated in previous Knowledge Gap theory studies.

To compare additional findings with Palm Coast, regression models were also completed to test other predictor variables of gender and age related to prior enrollment in CodeRED Weather Warning. A p-value of .01 ( $\mathrm{p}<.05)$ indicates older age is associated with prior enrollment in CodeRED Weather Warning.

\begin{tabular}{|c|c|c|c|c|}
\hline \multicolumn{5}{|c|}{$\begin{array}{c}\text { Douglas County Logistic Regression of Age vs. Prior Enrollment in } \\
\text { CodeRED Weather Warning as the Dependent Variable }\end{array}$} \\
\hline \multicolumn{5}{|c|}{ Omnibus Tests of Model Coefficients } \\
\hline & & Chi-Square & df & Sig. \\
\hline \multirow{3}{*}{\multicolumn{2}{|c|}{ Step $1 \quad$ Step }} & 6.9 & 1 & .01 \\
\hline & & 6.9 & 1 & .01 \\
\hline & & 6.9 & 1 & .01 \\
\hline
\end{tabular}

Table 13

When gender was tested against prior enrollment, a p-value of .05 was found.

Gender is in fact associated with the respondent's prior enrollment in CodeRED Weather Warning.

\begin{tabular}{|c|c|c|c|}
\hline Douglas Count & $\begin{array}{l}\text { ession of Ger } \\
\text { rning as the }\end{array}$ & aria & Coder \\
\hline & Tests of Mo & & \\
\hline & Chi-Square & $\mathrm{df}$ & Sig. \\
\hline Step $1 \quad$ Step & 3.83 & 1 & .05 \\
\hline & 3.83 & 1 & .05 \\
\hline & 3.83 & 1 & .05 \\
\hline
\end{tabular}

Table 14 
H2b: Citizens who were registered for their community's CodeRED Weather Warning service prior to the tornado were more confident they would receive future warnings in time to be safe more than those who were not enrolled in CodeRED Weather Warning prior to the tornado. In the supplemental question in the Web surveys for both communities, respondents were asked to indicate how much they agreed or disagreed with the statement "I feel confident that if there is another tornado warning in the future, I will receive it in time to be safe," with 5 indicating they strongly agreed or 1 meaning they strongly disagreed. A cross-tabulation analysis was determined to be the best way to analyze the categorical data to determine the relationship between the variables. Chi-squares were the primary statistic used for testing the statistical significance of the cross-tabulation tables.

Palm Coast, FL. Of those respondents who were registered for CodeRED Weather Warning prior to the December tornado, $82.1 \%$ indicated a response value of 5 , that they strongly agreed with the statement that they would receive future warnings in time to be safe, compared to $17.9 \%$ of respondents who were not registered prior to the storm. A Chi-square of .01 indicates there is in fact a relationship between prior enrollment in CodeRED Weather Warning and the highest confidence level that future warnings would be received in time to be safe. See Table 15 on the following page for a descriptive analysis of the results. 


\begin{tabular}{|c|c|c|c|c|c|}
\hline \multicolumn{6}{|c|}{$\begin{array}{c}\text { Palm Coast Crosstabulation Analysis of Prior Enrollment in CRWW and Confidence } \\
\text { to Receive Future Warnings as Dependent Variable }\end{array}$} \\
\hline & \multicolumn{5}{|c|}{ Confidence level } \\
\hline & 1 & 2 & 3 & 4 & 5 \\
\hline Registered for CRWW Yes & 35 & 32 & 114 & 85 & 247 \\
\hline Registered for CRWW & 19 & 20 & 33 & 23 & 54 \\
\hline $\begin{array}{l}\text { Pearson Chi-Square .01 } \\
\text { Asymp. Sig (2-sided) }\end{array}$ & & & & & \\
\hline
\end{tabular}

Douglas County, IL. Of those respondents who were registered for CodeRED Weather Warning prior to the December tornado, $80.8 \%$ indicated a response value of 5 , that they strongly agreed with the statement that they would receive future warnings in time to be safe, compared to $19.2 \%$ of respondents who were not registered prior to the storm. A Chi-square of .17 indicates there is not a relationship between prior enrollment in CodeRED Weather Warning and the highest confidence level that future warnings would be received in time to be safe.

\section{H3: Citizens of a higher SES will be more likely to have taken action to relocate to a} safe place after receiving the emergency tornado alert more than those of lower SES. Linear regressions were used to model the value of the dependent scale variable (action taken) based on its linear relationship to one or more predictors (education, income). 
The action taken variable was a constant; respondents selected whether or not they had taken action to shelter in a safe place indoors, shelter in a safe place outdoors or take no action. Since the values of the variable were not dichotomous, the researcher did not include the constant in the linear regression equation.

Palm Coast, $\boldsymbol{F L}$. The ANOVA table indicated the regression model predicted the outcome variable significantly well for all dependent scales. $\mathrm{P}<.05$, indicating that the model applied can statistically significantly predict the outcome variable. Both education and total household income contribute significantly to the model. With a low probability of a Type I error, the significance test led the researcher to reject the null hypothesis.

\section{Palm Coast ANOVA Table of Linear Regression}

\begin{tabular}{ll|l|l|l}
\hline $\begin{array}{l}\text { Education and Income vs. Relocating to Safe Place } \\
\text { Inside as the Dependent Variable }\end{array}$ & df & F & Sig. \\
\hline
\end{tabular}

Note: More income and higher education are associated with the likelihood of taking action to relocate to a safe place once a tornado warning was received, significant at the $\mathrm{p}<.05$ level.

Table 16

In Palm Coast, the findings of this analysis support the combination of Diffusion of Innovations, Knowledge Gap and Structuration theories; a person with more education and a higher income will have adopted a particular technology to receive the tornado warning, they acquire more knowledge and ultimately are more informed to make a decision to protect themselves more easily than those of a lower SES.

The so-called "Starlight Tornado" hit Palm Coast on Saturday December 14, 2013 at 7:03 p.m. ET. Because this event occurred on the weekend and therefore commuting may not have been an issue, it stands to reason that most Palm Coast residents would have been able to take shelter in a safe place indoors if suggested by officials. 
Douglas County, IL. The ANOVA table indicated the regression model predicted the outcome variable significantly well for two of the three dependent scales: went to safe place inside and took no action. The p-values were 0 ; the model applied can statistically significantly predict the outcome variable. Both education and total household income contribute significantly to two of the models. The significance test for two of the three variables led the researcher to reject the null hypothesis. More income and higher education are associated with the likelihood of relocating to a safe place inside and taking no action once a tornado warning was received. The findings of this regression support the combination of the three theories and the hypothesis; those with more income and higher education adopted the technology to receive the warning, received the warning and took action to protect themselves and stay safe, more than those with less income and less education.

When the dependent variable took shelter at a safe place outside was tested against the predictor values income and education, the p-value for education level was .06 , not significant above the .05 level. The $\mathrm{p}$-value for annual household income was .50 , also not significant above the .05 level. The significance tests led the researcher to fail to reject a null hypothesis; as SES relates to action taken, there is no association between education and income and a respondent's decision to take shelter outside. This finding negates the Knowledge Gap and Structuration theory; only the Diffusion of Innovations fits as the respondent received a tornado warning. The findings did not support that the more educated or higher paid have more knowledge and therefore can benefit from their SES to stay safe. 
The EF-3 tornado touched down in Douglas County on Sunday, November 17, 2013 at 1:44 p.m. ET. It stands to reason that since the tornado did not occur during the work week, relocating to a safe place would not have been an issue. 


\section{Discussion}

The researcher chose to keep the Palm Coast and Douglas County databases separate for hypotheses testing and theory support. It was important to determine a comparison between the two communities to find if response and behavior was complementary regardless of geographic distance, or if there were differences that are specific to their geographic location. In 2010, Fortune magazine ranked Palm Coast as of the nation's five best places to retire with a population of "active seniors" (5 great places to retire, 2010). With Palm Coast having a likely older population sample than Douglas County, IL it was important to keep the databases separate for accurate hypotheses testing. Though similarities were found across both communities, there were significant differences supported by theory and make substantial contributions to disaster communication research and to the individual communities themselves.

The digital divide, as it relates to this study, does not exist. Socioeconomic status did not appear to impact the ownership or ability for respondent's to receive information. In fact, John Rawls Theory of Justice was most appropriate to generalize the findings of this study. Both Palm Coast and Douglas County provide their residents the opportunity to be notified of tornado warnings that affect them. They provide the CRWW technology as an added benefit, even above warnings residents are able to receive through more traditional means including the television and radio. This opportunity is open regardless of income, education, age and gender. 
Although there is equal access to "gain" the information at a level start, the behavior to adopt the technology in terms of the Diffusion of Innovations is not always taken advantage of. If the resident does not see value in the technology, the continuing process of acquiring technology and being more informed may never happen.

Most existing research used for this study focused on the abilities of new technology to communicate during disaster, not on the actual receipt of the message which is problematic; if new technology is being utilized to distribute an emergency message but there are portions of the population cannot receive the message or do not act on the information received, is there an unspoken liability regarding a public safety organization's protection of life and property? The information gathered from this research will be shared with the participating agencies to help not only state and local public safety organizations understand how people receive and act on safety information, but also the federal government as planning and implementation of national emergency alerting initiatives continues.

The research will help answer the questions faced by emergency management officials nationwide: What actionable items can we take to ensure our population has access to emergency tornado information, and what can be done to improve the way we communicate with citizens during an emergency? The research will allow for further inquiry into the behavior of individuals during an emergency for future psychology studies, and to contribute to the knowledge base of existing research on disaster communication. 
Both communities studied in this survey were represented by mostly White respondents. A similar study in communities with predominant races outside of White should be conducted to determine the actions of other races and ethnicities. Cultural heritage may have a lot to do with how people receive and react to information, especially with receiving information from a friend, family member in neighborhood for certain races, and the results of a more culturally diverse community would shed new light on their receipt of tornado warnings and behavior.

There are a wide variety of disasters beyond tornadoes, and communities that are impacted by a variety of life threatening weather events. As this research focuses specifically on tornado emergency notifications, therefore surveying only those impacted by a tornado threat, limitations on applying behavior and message delivery results will exist when attempting to correlate results to the general population. Research may not be easily replicated if future researchers do not have the ability to leverage professional relationships with government entities to help solicit survey participation and responses.

Disaster communication can be achieved in a multi-method approach. This study focused on cellphones, landlines, tornado sirens and word of mouth warnings; however the study of additional communication devices can and should be explored. The use of social media for emergency communication, including Facebook, Twitter and Instagram may lend itself to additional research into the behaviors of citizens receiving information from law enforcement in a social setting and how their actions may differ from receiving information from more traditional communication methods. 


\section{References}

(2010, May 27). 5 great places to retire. Retrieved from CNN Money website: http://money.cnn.com/galleries/2010/fortune/1005/gallery.retire_rich_places.fortu ne/6.html

(2013, September 28). Local television market universe estimates. Retrieved from Nielsen 2013-2014 DMA Ranks website: http://www.tvb.org/media/file/TVB_Market_Profiles_Nielsen_TVHH_DMA_Ra nks_2013-2014.pdf

About us. (2013). Retrieved from Qualtrics website: http://qualtrics.com/about/

Annual severe weather report summary (2013, December 1). 2013. Retrieved from NOAA's National Weather Service Storm Prediction Center website: http://www.spc.noaa.gov/climo/online/monthly/1311_summary.html

Bethel, J., Foreman, A., \& Burke, S. (2011). Disaster preparedness among medically vulnerable populations. American Journal of Preventative Medicine, 40(2), 139143. Retrieved from http://www.sciencedirect.com.proxy.mul.missouri.edu/science/article/pii/S074937 9710006136

Bradford, M. (1999). Historical roots of modern tornado forecasts and warnings. Weather and Forecasting, 14(4), 484-491. Retrieved from http://search.proquest.com/docview/196332932?accountid=14576

Coleman, T. A., Knupp, K. R., Spann, J., Elliott, J. B., \& Peters, B. E. (2011). THE HISTORY (AND FUTURE) OF TORNADO WARNING DISSEMINATION IN THE UNITED STATES. Bulletin of the American Meteorological Society, 92(5), 567-582. Retrieved from http://search.proquest.com/docview/874327092?accountid=14576

Collins, M. L., \& Kapucu, N. (2008). Early warning systems and disaster preparedness and response in local government. Disaster Prevention and Management, 17(5), 587-600. Retrieved from http://search.proquest.com.proxy.mul.missouri.edu/docview/214389162 
Crang, M., Crosbie, T., \& Graham, S. (2006). Variable Geometries of Connection: Urban Digital Divides and the Uses of Information Technology. Urban Studies, 43(13), 2551-2570. Retrieved from http://usj.sagepub.com.proxy.mul.missouri.edu/content/43/13/2551

Creswell, J. W. (2009). Research Design: Qualitative, Quantitative, and Mixed Methods Approaches. California: SAGE Publications, Inc.

Demiray, E. (2010). Information Technologies and Women. (Undetermined). Distance Learning, 7(1), 1-15.

Department of Commerce. (2013, May 24). Weather warnings on the go! Retrieved from Weather-Ready Nation website: http://www.nws.noaa.gov/com/weatherreadynation/wea.html\#.Uj9RqIWBgoU

Digital Inclusion. (2010). IT NOW, 52(6), 6-7. Retrieved from http://itnow.oxfordjournals.org.proxy.mul.missouri.edu/content/52/6/6.full.pdf+ht $\mathrm{ml}$

Duff, A. S. (2010). The Rawls-Tawney theorem and the digital divide in postindustrial society. Journal of the American Society for Information Science and Technology, 62(3), 604-612. Retrieved from http://onlinelibrary.wiley.com.proxy.mul.missouri.edu/doi/10.1002/asi.21470/full

Durage, S. W., Wirasinghe, S. C., \& Ruwanpura, J. (2013). Comparison of the Canadian and US tornado detection and warning systems. Journal of the International Society for the Prevention and Mitigation of Natural Hazards, 66(1), 117-137. Retrieved from http://link.springer.com.proxy.mul.missouri.edu/article/10.1007\%2Fs11069-0120168-7/fulltext.html

Gunkel, D. (2003). Second Thoughts: Toward a Critique of the Digital Divide. New Media Society, 5(4), 499-522. Retrieved from http://nms.sagepub.com.proxy.mul.missouri.edu/content/5/4/499.full.pdf+html

Harper, F. (2011). Bullard looks to implement Code Red. Jacksonville Daily Progress. Retrieved from http://jacksonvilleprogress.com/local/x202400660/Bullard-looksto-implement-Code-Red/print 
Heath, R. L. (2005). Diffusion of innovations theory. Encyclopedia of Public Relations, $1,253-254$. Retrieved from http://go.galegroup.com.proxy.mul.missouri.edu/ps/i.do?action=interpret\&id=GA LE $\mid C X 3439100131 \& v=2.1 \& u=$ morenetuomcolum\&it=r\&p=GVRL\&sw=w\&auth Count $=1$

Hendrix, E. (2005). Permanent Injustice: Rawls' Theory of Justice and the Digital Divide. Educational Technology \& Society, 8 (1), 63-68.

Laidlaw, E. (2010). The controversy over outdoor warning sirens. Weatherwise, 63(1), 17-25. Retrieved from http://ehis.ebscohost.com.proxy.mul.missouri.edu/ehost/pdfviewer/pdfviewer?sid $=\mathrm{fdc} 4 \mathrm{c} 3 \mathrm{f} 7-\mathrm{f} 7 \mathrm{ea}-4 \mathrm{c} 0 \mathrm{f}-896 \mathrm{e}-\mathrm{f} 2 \mathrm{~b} 72 \mathrm{e} 70 \mathrm{fa} 52 \% 40$ sessionmgr10\&vid=2\&hid=6

Maeve, D. (2013, September 16). Cell phone activities 2013. Retrieved from Pew Research Center website: http://pewinternet.org/ /media//Files/Reports/2013/PIP_Cell\%20Phone\%20Activi ties\%20May\%202013.pdf

Malizia, A., Onorati, T., Diaz, P., Aedo, I., \& Astorga-Paliza, F. (2010). SEMA4A: An ontology for emergency notification systems accessibility. Expert Systems with Applications, 37(4), 3380-3391. Retrieved from http://www.sciencedirect.com.proxy.mul.missouri.edu/science/article/pii/S095741 7409008768.

Mason, S. M., \& Hacker, K. L. (2003). Applying communication theory to digital divide research. IT\&Society, 1(5), 40-55.

McGrath, C., \& Zell, D. (2001). The future of innovation diffusion research and its implications for management: A conversation with Everett Rogers. Journal of Management Inquiry, 10(4), 386-391. Retrieved from http://search.proquest.com/docview/203315226? accountid=14576

McKoppin, R. (2003, July 10). Will weather sirens keep you safe? Towns' varying criteria make it hard to know the answer. Daily Herald. Retrieved from http://search.proquest.com.proxy.mul.missouri.edu/docview/312757224 
Modarres, A. (2011). Beyond the digital divide. National Civic Review, 100(3), 4-7. Retrieved from http://onlinelibrary.wiley.com.proxy.mul.missouri.edu/doi/10.1002/ncr.20069/abs tract

Moussavian, Amir. "This is not your mother's notification platform." Software World Nov. 2010: 19+. Business Insights: Essentials. Web. 4 Sept. 2013.

Neeley, O. (2011, Jul 06). CodeRED offers weather warnings. McClatchy - Tribune Business News. Retrieved from http://search.proquest.com/docview/874984447?accountid=14576

Norvell, K. (2012, Jun 26). New system delivers weather warnings to cell phones. McClatchy - Tribune Business News. Retrieved from http://search.proquest.com/docview/1022098326?accountid=14576

Payne, D. (1998, May 17). Horns of dilemma: Use of storm sirens stirs debate. The Atlanta Journal the Atlanta Constitution. Retrieved from http://search.proquest.com/docview/247564082? accountid=14576

Pearson, M. (2006, Apr 30). Silent storm sirens raise alarm: Failures prompt fixes in emergency procedures. The Atlanta Journal - Constitution. Retrieved from http://search.proquest.com/docview/337313091 ?accountid=14576

Rice, R. (2003). Comparing Internet and mobile phone usage: digital divides of usage, adoption, and dropouts. Telecommunications Policy, 27(8-9), 597-623. Retrieved from http://www.sciencedirect.com.proxy.mul.missouri.edu/science/article/pii/S030859 6103000685\#.

Rice, R., \& Katz, J. (2003). Comparing internet and mobile phone usage: digital divides of usage, adoption, and dropouts. Telecommunications Policy, 27(8-9), 597-623. Retrieved from http://www.sciencedirect.com.proxy.mul.missouri.edu/science/article/pii/S030859 6103000685 
Sacchi, A., Giannini, E., Bochic, R., Reinhard, N., \& Lopes, A. (2009). Digital inclusion with the McInternet: would you like fries with that? Communications of the ACM - Being Human in the Digital Age, 52(3), 113-116. Retrieved from http://cacm.acm.org.proxy.mul.missouri.edu/magazines/2009/3/21794/fulltext

Sherman-Morris, K. (2009). Tornado warning dissemination and response. Nat Hazards, 52, 623-628. Retrieved from http://download.springer.com.proxy.mul.missouri.edu/static/pdf/632/art\%253A10 $.1007 \% 252$ Fs $11069-009-9405-$ 0.pdf?auth66=1380218869_27668984b03c5203b2c375e33f33722e\&ext=.pdf

Sipior, J., Ward, B., \& Connolly, R. (2011). The digital divide and t-government in the United States: using the technology acceptance model to understand usage. European Journal of Information Systems, 20(3), 308-328. Retrieved from http://search.proquest.com.proxy.mul.missouri.edu/docview/863865877.

Spence, P., Lachlan, K., \& Burke, J. (2011). Differences in crisis knowledge across age, race, and socioeconomic status during hurricane ike: A field test and extension of the knowledge gap hypothesis. Communication Theory, 21(3), 261-278. Retrieved from http://onlinelibrary.wiley.com.proxy.mul.missouri.edu/doi/10.1111/j.14682885.2011.01385.x/full

Spence, P., Lachlan, K., \& Griffin, D. (2007). Crisis communication, race, and natural disasters. Journal of Black Studies, 37(4), 539-554. Retrieved from http://www.jstor.org.proxy.mul.missouri.edu/stable/40034322

Sundar, S. S., \& Nass, C. (2001). Conceptualizing sources in online news. Journal of Communication, 52-72.

Tanner, A., Friedman, D., Koskan, A., \& Barr, D. (2009). Disaster communication on the internet: A focus on mobilizing information. Journal of Health Communication: International Perspectives, 14(8), 741-755. Retrieved from http://www.tandfonline.com.proxy.mul.missouri.edu/doi/pdf/10.1080/108107309 03295542

TORNADO FORECASTING AND WARNING. (2006). Bulletin of the American Meteorological Society, 87(7), 972-976. Retrieved from http://search.proquest.com/docview/232611632?accountid=14576 
U.S. Census Bureau. (2010, April 1). Douglas County quickfacts from the US Census Bureau. Retrieved from United States Census Bureau website: http://quickfacts.census.gov/qfd/states/17/17041.html

U.S. Census Bureau. (2010, April 1). Palm Coast quickfacts from the US Census Bureau. Retrieved from United States Census Bureau website: http://quickfacts.census.gov/qfd/states/12/1254200.html

Wei, L., \& Hindman, D. (2011). Does the Digital Divide Matter More? Comparing the Effects of New Media and Old Media Use on the Education-Based Knowledge Gap. Mass Communication and Society, 14(2), 216-235. Retrieved from http://www.tandfonline.com.proxy.mul.missouri.edu/doi/abs/10.1080/152054310 03642707.

West, D. M., \& Orr, M. (2007). Race, gender, and communications in natural disasters. Policy Studies Journal, 35(4), 569-586. Retrieved from http://search.proquest.com/docview/210535597? accountid=14576

Wing, S. (2012). Mobile and wireless communication: Space weather threats, forecasts, and risk management. IT Professional, 14(5), 40-46. Retrieved from http://ieeexplore.ieee.org.proxy.mul.missouri.edu/stamp/stamp.jsp?tp=\&arnumber $=6212428$

Zickuhr, K. (2012, June 25). Digital differences. Retrieved from Pew Internet \& American Life Project website: http://pewinternet.org/Presentations/2012/Jun/Digital-differences.aspx 


\title{
Appendix A
}

\author{
NEWS RELEASE - City of Palm Coast \\ Contact: Cindi Lane, Communications \& Marketing Manager
}

386-986-3708; cell 386-214-4729

Feb. 3, 2014

\section{City of Palm Coast to participate in university research regarding emergency notification}

Palm Coast, Fla. - The City of Palm Coast is participating in a new University of Missouri-Columbia research study regarding emergency tornado notification.

On Dec. 14, 2013, the National Weather Service reported an EF-1 tornado with maximum winds of $110 \mathrm{mph}$ that touched down and crossed the northern sections of Palm Coast. The survey will help researchers learn how residents and businesses inside the City were notified of the tornado threat and what they did with the information, in an effort to understand how people receive and react to emergency information.

The survey will be open Monday, Feb. 3, through Monday, Feb. 17. The researchers are asking all adults (age 18 or older) who live(d) in Palm Coast in December 2013 to participate in the survey - whether they live(d) in the neighborhoods affected by the Starlight Tornado or not.

The survey may be completed online by visiting the City website at www.palmcoastgov.com and clicking on the CodeRED logo. Those who would prefer to complete the survey by telephone may call toll-free at 800-453-8436.

The results of the survey will be shared with the City of Palm Coast in an effort to continuously improve emergency communication initiatives and outreach. The City currently utilizes the CodeRED emergency notification system to provide automated warnings of impending severe thunderstorms, tornadoes and flash floods, as well as City or neighborhood emergency alerts. To register for future notifications, visit www.palmcoastgov.com to submit information into the emergency database, which will only be used for Palm Coast emergency alerts.

"We are very excited that our City was selected to participate in this survey, and we look forward to partnering with the University of Missouri-Columbia for this research initiative," said Palm Coast Fire Chief Mike Beadle. "We encourage all of our residents who are over 18 to make sure they participate. The findings of this research will help us understand any communication limitations that exist within our community and ways we can improve early warning communication to our citizens to protect life and property." 
The University of Missouri-Columbia study will also survey residents and businesses in Douglas County, Ill., which was impacted by an EF-3 tornado in November 2013 for a comparison of emergency notification technology utilized and how it was received by the public for weather warning notification. The principal investigator of this research is Stephanie Meyers, graduate student at the University of Missouri-Columbia.

\section{For more information, contact:}

City of Palm Coast: Cindi Lane, 386-986-3708, clane@ palmcoastgov.com

University of Missouri-Columbia: Stephanie Meyers, 386-944-7269 ext. 1178, seghx4@mail.missouri.edu 


\section{Appendix B}

\section{Douglas County to participate in new university research regarding emergency tornado notification February 3, 2014}

Douglas County has been selected to participate in a new University of MissouriColumbia research study regarding emergency tornado notification. On November 17, 2013, the National Weather Service reported an EF-3 tornado a 1/4 mile wide with peak winds of $140 \mathrm{mph}$ and a path length of 15 miles in Douglas County as part of a major late-season severe weather outbreak. The survey will help researchers learn how residents and businesses inside the County were notified of the tornado threat and what they did with the information in an effort to understand how people receive and react to emergency information.

The survey will be open February 3, 2014 through February 17, 2014. Anyone who lived in Douglas County in November 2013 and are 18 years or older are asked to participate in the survey. The survey may be completed online by visiting the Douglas County website at www.douglascountyil.com and clicking on the CodeRED logo. Those who would prefer to complete the survey by telephone are encouraged to call toll-free 800-430-1299.

The results of the survey will be shared with Douglas County Emergency Management in an effort to continuously improve emergency communication initiatives and outreach. Douglas County has been using the CodeRED emergency notification system since September 2008 to provide automated warnings of impending severe thunderstorms, tornadoes and flash floods, as well as County-wide or neighborhood specific emergency alerts. To register for future notifications, visit www.douglascountyil.com and click on the CodeRED logo to submit information into the emergency database, which will only be used for Douglas County related emergency alerts.

"Douglas County is excited for the opportunity to participate in the survey and we look forward to partnering with the University of Missouri-Columbia for this research. We were hit hard by a late season tornado in November, and this research will help us understand how people in our community receive and react to information we send out about tornadoes for future storms," said Joe Victor, Douglas County EMA.

The University of Missouri-Columbia study will also survey residents and businesses in Palm Coast, FL that was impacted by a EF-1 tornado in December 2013 for a comparison of emergency notification technology utilized and how it was received by the public for weather warning notification. The principal investigator of the research is Stephanie Meyers, graduate student at the University of Missouri-Columbia. 


\section{For media inquiries:}

> Douglas County: Joe Victor, Douglas County EMA, 217-253-9538, joe.victor@douglascountyil.com

> University of Missouri-Columbia: Stephanie Meyers, 386-944-7269 ext 1178, $\underline{\text { seghx4@mail.missouri.edu }}$ 


\title{
Appendix C
}

\author{
NEWS RELEASE - City of Palm Coast \\ Contact: Cindi Lane, Communications \& Marketing Manager
}

386-986-3708; cell 386-214-4729

Feb. 10, 2014

Additional survey participants requested for emergency notification research

Palm Coast, Fla. - The City of Palm Coast is encouraging more residents to participate in a University of Missouri-Columbia research study regarding emergency tornado notification. The City would like to thank those who have already participated and provided their information regarding the recent Starlight Tornado. To take the survey, visit www.palmcoastgov.com and click on CodeRED. Those without Internet access or who would prefer to complete the survey over the telephone are asked to call toll-free 800-453-8436. Residents must be 18 or older to participate in the research.

"We want to continue to encourage everyone to take the survey before it ends on the $17^{\text {th }}$ of this month, whether your neighborhood was affected by the tornado or not," said Palm Coast Fire Chief Mike Beadle. "The survey takes only a few minutes of your time and will help us plan for future emergencies."

The City of Palm Coast was selected to participate in the research study based on its experience with the late-season Starlight Tornado, an EF-1 tornado that touched down Dec. 14, 2013, leaving a path of destruction across the northern sections of Palm Coast. The survey will help researchers learn how residents and businesses inside the City were notified of the tornado threat and what they did with the information, in an effort to understand how people receive and react to emergency information.

The principal researcher, Stephanie Meyers, an Ormond Beach resident and graduate student at the University of Missouri-Columbia's School of Journalism, is also surveying residents and businesses in Douglas County, Ill., which was impacted by an EF-3 tornado in November 2013 for a comparison.

\section{For more information, contact:}

City of Palm Coast: Cindi Lane, 386-986-3708, clane@ palmcoastgov.com

University of Missouri-Columbia: Stephanie Meyers, 386-944-7269 ext. 1178, seghx4@mail.missouri.edu 


\section{Appendix D}

\section{Additional survey participants needed for research regarding emergency tornado notification in Douglas County}

\section{February 10, 2014}

More Douglas County residents are needed to participate in a University of MissouriColumbia research study emergency tornado notification. Douglas County EMA would like to thank those who have already participated. To take the survey, visit douglascountyil.com and click on CodeRED Weather Warning. Those without Internet access or who would prefer to complete the survey over the telephone are asked to call toll-free 800-430-1299. Residents must be 18 or older to participate in the research.

"The more Douglas County residents that participate in the survey, the better understanding we will have of how people in our community receive tornado warnings. The survey takes only a few minutes of your time and will provide both the University and our Emergency Management Agency critical information as we prepare for the next round of tornadoes in Douglas County," said Joe Victor, Douglas County EMA.

Douglas County was selected to participate in the new research study because of the November 17, 2013 EF-3 tornado that destroyed several homes, buildings and tore down power lines throughout the county. The survey will help researchers understand how residents and businesses within Douglas County were alerted to the tornado and what they did with the information. The principal investigator for the research is Stephanie Meyers, graduate student at the University of Missouri-Columbia.

The survey will close February 17, 2014. The results of the survey will be shared with Douglas County Emergency Management in an effort to continuously improve emergency communication initiatives and outreach. Douglas County has been using the CodeRED emergency notification system since September 2008 to provide automated warnings of impending severe thunderstorms, tornadoes and flash floods, as well as County-wide or neighborhood specific emergency alerts. To register for future notifications, visit www.douglascountyil.com and click on the CodeRED logo to submit information into the emergency database, which will only be used for Douglas County related emergency alerts.

The researcher is also surveying residents and businesses in Palm Coast, FL who were impacted by an EF-1 tornado in December 2013 for a comparison of emergency notification technology utilized and how it was received by the public for weather warning notification. 


\section{For media inquiries:}

> Douglas County: Joe Victor, Douglas County EMA, 217-253-9538, joe.victor@douglascountyil.com

> University of Missouri-Columbia: Stephanie Meyers, 386-944-7269 ext 1178, $\underline{\text { seghx4@mail.missouri.edu }}$ 


\section{Appendix E}

SURVEY WELCOME: The research title for this study is: The Effects of New Media for Emergency Tornado Notification on the Digital Divide. The principal investigator for this research is Stephanie Meyers, Graduate Student at the University of MissouriColumbia. She may be contacted by email at seghx4@mail.missouri.edu.

Participation in this research project is completely voluntary. You have the right to say no. You may change your mind at any time and withdraw. You may choose not to answer specific questions or to stop participating at any time.

The purpose of this research is to determine the size and impact, if any, of the digital divide when it comes to receiving emergency tornado messages. Technology continues to present new, advanced methods of communicating but it has also created a modern day digital divide - separating audiences based on their ability to receive warnings because of socioeconomic or demographic differences.

Thank you for calling the Douglas County telephone-based tornado survey. Douglas County, along with the University of Missouri-Columbia and Emergency Communications Network, the company that provides your county CodeRED emergency notification services, would like to thank you for your interest in this survey. Questions in this survey regard the EF-3 tornado that hit Douglas County on November 17, 2013. Please note that you should only complete this survey if you are over the age of 18 and lived in Douglas County in November 2013 to make sure the findings of this research are accurate.

This survey may take up to 15 minutes to complete. Make sure to listen to all of the answer choices carefully before indicating your response using your telephone's touchtone keypad. If you would prefer to complete this survey online, please visit douglascountyil.com. The survey will begin now.

Q33: Were you in or near Douglas County on November 17, 2013 when the tornado hit? Press 1 for yes or 2 for no.

Q36: Before the tornado hit, did you know there was a possibility of tornadoes in Douglas County that day? Press 1 for yes or 2 for no.

Q14: Where you were when you received an emergency tornado warning about the November 17, 2013 tornado? Press 1 for home, press 2 for work, 3 for school or 4 for other.

Q32: Were you registered to receive CodeRED Weather Warnings through Douglas County prior to the tornado on November 17, 2013? Press 1 for yes or 2 for no. 
SECTION BREAK: The next set of questions are about the types of things you own that you use to communicate.

Q5: Do you own a landline telephone? Press 1 for yes, 2 for no.

Q39: Do you own a cell phone? Press 1 for yes, 2 for no.

Q40: Do you own a TV? Press 1 for yes, 2 for no.

Q41: Do you own a weather radio? Press 1 for yes, 2 for no.

Q42: Do you own a desktop computer, laptop or tablet that receives emails? Press 1 for yes, 2 for no.

SECTION BREAK: The next set of questions are how you received notification of the November 17, 2013 tornado.

Q13: Did you receive a tornado warning on a landline telephone? Press 1 for yes, 2 for no.

Q43: Did you receive a tornado warning on a cell phone? Press 1 for yes, 2 for no.

Q44: Did you receive a tornado warning through the television? Press 1 for yes, 2 for no.

Q45: Did you receive a tornado warning through a desktop computer, laptop or tablet? Press 1 for yes, 2 for no.

Q46: Did you receive a tornado warning through an outdoor warning or storm siren? Press 1 for yes, 2 for no.

Q47: Did you receive a tornado warning through a neighbor, friend or family member? Press 1 for yes, 2 for no.

Q16: What immediate action did you take after receiving the emergency tornado warning? Press 1 for went to a safe place inside, press 2 for went to a safe place outside or press 3 for took no action. 


\section{SECTION BREAK: The survey is about halfway done. Thank you again for participating. We'll move on to the next set of questions.}

Q38: Would you describe the area where you live as rural or suburban? Press 1 for rural, 2 for suburban.

Q1: What age group are you in? If you are between the ages of 18 and 24, press 1. If you're between the ages of 25 and 34, press 2 . Press 3 for 35-44, press 4 for $45-54$ or press 5 if you are older than 54 .

Q21: What is the highest level of education you have completed? Press 1 for some high school, press 2 for GED/high school diploma, press 3 for associate's degree, press 4 for bachelor's degree, 5 for master's degree or press six if you completed your Ph.D.

Q22: What is your yearly individual income? Press 1 for less than $\$ 15,000$. Press 2 if your income is between $\$ 15,000$ and $\$ 34,999$. Press 3 if your income is between $\$ 35,000$ and $\$ 54,999$. Press 4 if your income is $\$ 55,000$ to $\$ 74,999$. Press 5 if your yearly personal income is higher than $\$ 75,000$.

Q23: What is your annual household income? Press 1 for less than $\$ 30,000$. Press 2 for $\$ 30,000$ to $\$ 49,999$. Press 3 if your household income falls between $\$ 50,000$ and $\$ 74,999$. Press 4 for $\$ 75,000$ to $\$ 94,999$. Or press 6 if your annual household income is above $\$ 95,000$.

\section{SURVEY BREAK: Just a few more questions. You're almost done.}

Q24: How would you describe your race or ethnicity? Press 1 for white or Caucasian, press 2 for Hispanic or Latino. Press 3 for black or African American, press 4 for Asian American, Native Hawaiian, or Pacific Islander. Press 5 for American Indian or Native American. Press 6 for Multi-racial or multi ethnic. Or, press 7 for other.

Q26: What is your gender? Press 1 for male, 2 for female.

Q31: What is your marital status? Press 1 for single, 2 for married or domestic partnership, press 3 if you are widowed, 4 for divorced or 5 for separated.

SURVEY COMPLETE: The survey is complete! Thank you for taking the Douglas County telephone-based tornado survey. Your contribution is very much appreciated. For more information about the survey, please visit douglacountyil.com. Goodbye! 


\section{Appendix F}

SURVEY WELCOME: The research title for this study is: The Effects of New Media for Emergency Tornado Notification on the Digital Divide. The principal investigator for this research is Stephanie Meyers, Graduate Student at the University of MissouriColumbia. She may be contacted by email at seghx4@mail.missouri.edu.

Participation in this research project is completely voluntary. You have the right to say no. You may change your mind at any time and withdraw. You may choose not to answer specific questions or to stop participating at any time.

The purpose of this research is to determine the size and impact, if any, of the digital divide when it comes to receiving emergency tornado messages. Technology continues to present new, advanced methods of communicating but it has also created a modern day digital divide - separating audiences based on their ability to receive warnings because of socioeconomic or demographic differences.

Thank you for calling the City of Palm Coast's telephone-based tornado survey. The City of Palm Coast, along with the University of Missouri-Columbia and Emergency Communications Network, the company that provides your county CodeRED emergency notification services, would like to thank you for your interest in this survey. Questions in this survey regard the EF-1 tornado that hit Palm Coast on December 14, 2013. Please note that you should only complete this survey if you are over the age of 18 and lived in Palm Coast in December 2013 to make sure the findings of this research are accurate.

This survey may take up to 15 minutes to complete. Make sure to listen to all of the answer choices carefully before indicating your response using your telephone's touchtone keypad. If you would prefer to complete this survey online, please visit palmcoastgov.com. The survey will begin now.

Q33: Were you in or near Palm Coast on December 14, 2013 when the tornado hit? Press 1 for yes or 2 for no.

Q36: Before the tornado hit, did you know there was a possibility of tornadoes in Palm Coast that day? Press 1 for yes or 2 for no.

Q14: Where you were when you received an emergency tornado warning about the December 14, 2013 tornado? Press 1 for home, press 2 for work, 3 for school or 4 for other.

Q32: Were you registered to receive CodeRED Weather Warnings through Palm Coast prior to the tornado on December 14, 2013? Press 1 for yes or 2 for no. 
SECTION BREAK: The next set of questions are about the types of things you own that you use to communicate.

Q5: Do you own a landline telephone? Press 1 for yes, 2 for no.

Q39: Do you own a cell phone? Press 1 for yes, 2 for no.

Q40: Do you own a TV? Press 1 for yes, 2 for no.

Q41: Do you own a weather radio? Press 1 for yes, 2 for no.

Q42: Do you own a desktop computer, laptop or tablet that receives emails? Press 1 for yes, 2 for no.

\section{SECTION BREAK: The next set of questions how you received notification of the December 15, 2013 tornado.}

Q13: Did you receive a tornado warning on a landline telephone? Press 1 for yes, 2 for no.

Q43: Did you receive a tornado warning on a cell phone? Press 1 for yes, 2 for no.

Q44: Did you receive a tornado warning through the television? Press 1 for yes, 2 for no.

Q45: Did you receive a tornado warning through a desktop computer, laptop or tablet? Press 1 for yes, 2 for no.

Q46: Did you receive a tornado warning through an outdoor warning or storm siren? Press 1 for yes, 2 for no.

Q47: Did you receive a tornado warning through a neighbor, friend or family member? Press 1 for yes, 2 for no.

Q16: What immediate action did you take after receiving the emergency tornado warning? Press 1 for went to a safe place inside, press 2 for went to a safe place outside or press 3 for took no action. 


\section{SECTION BREAK: The survey is about halfway done. Thank you again for participating. We'll move on to the next set of questions.}

Q38: Would you describe the area where you live as rural or suburban? Press 1 for rural, 2 for suburban.

Q1: What age group are you in? If you are between the ages of 18 and 24, press 1. If you're between the ages of 25 and 34, press 2 . Press 3 for 35-44, press 4 for $45-54$ or press 5 if you are older than 54 .

Q21: What is the highest level of education you have completed? Press 1 for some high school, press 2 for GED/high school diploma, press 3 for associate's degree, press 4 for bachelor's degree, 5 for master's degree or press six if you completed your Ph.D.

Q22: What is your yearly individual income? Press 1 for less than $\$ 15,000$. Press 2 if your income is between $\$ 15,000$ and $\$ 34,999$. Press 3 if your income is between $\$ 35,000$ and $\$ 54,999$. Press 4 if your income is $\$ 55,000$ to $\$ 74,999$. Press 5 if your yearly personal income is higher than $\$ 75,000$.

Q23: What is your annual household income? Press 1 for less than $\$ 30,000$. Press 2 for $\$ 30,000$ to $\$ 49,999$. Press 3 if your household income falls between $\$ 50,000$ and $\$ 74,999$. Press 4 for $\$ 75,000$ to $\$ 94,999$. Or press 6 if your annual household income is above $\$ 95,000$.

\section{SURVEY BREAK: Just a few more questions. You're almost done.}

Q24: How would you describe your race or ethnicity? Press 1 for white or Caucasian, press 2 for Hispanic or Latino. Press 3 for black or African American, press 4 for Asian American, Native Hawaiian, or Pacific Islander. Press 5 for American Indian or Native American. Press 6 for Multi-racial or multi ethnic. Or, press 7 for other.

Q26: What is your gender? Press 1 for male, 2 for female.

Q31: What is your marital status? Press 1 for single, 2 for married or domestic partnership, press 3 if you are widowed, 4 for divorced or 5 for separated.

SURVEY COMPLETE: The survey is complete! Thank you for taking the Palm Coast telephone-based tornado survey. Your contribution is very much appreciated. For more information about the survey, please visit www.palmcoastgov.com. Goodbye! 


\section{Appendix G}

Q28 Research Study Title: The Effects of New Media for Emergency Tornado Notification on the Digital Divide Principal Investigator: Stephanie Meyers, Graduate Student, University of Missouri-Columbia Contact information: seghx4@mail.missouri.edu

Participation in this research project is completely voluntary. You have the right to say no. You may change your mind at any time and withdraw. You may choose not to answer specific questions or to stop participating at any time. The purpose of this research is to determine the size and impact, if any, of the digital divide when it comes to receiving emergency tornado messages. Technology continues to present new, advanced methods of communicating but it has also created a modern day digital divide - separating audiences based on their ability to receive warnings because of socioeconomic or demographic differences.

The City of Palm Coast would like to thank you for your interest in this survey regarding the EF-1 tornado that touched down and crossed the northern sections of Palm Coast on December 14, 2013. Your participation in this survey shows your commitment to helping save lives and being a good citizen in Palm Coast.

The University of Missouri-Columbia, in conjunction with Emergency Communications Network, the providers of the CodeRED emergency notification system, would like to understand how residents of Palm Coast are notified of tornado threats. You are encouraged to respond to this survey ONLY if you are 18 or older and lived within Palm Coast city limits in December 2013 to ensure the findings of the research are accurate.

If you know of anyone else who lives in Palm Coast who may have also been impacted by the recent tornado, please also encourage them to participate in the survey.

Q33 Were you in or near Palm Coast on December 14, 2013 when the tornado hit?

Yes (1)

O No (2) 
Q36 Before the tornado hit, did you know there was a possibility of tornadoes in Palm Coast that day?

Yes (1)

No (2)

Q14 Where you were when you received an emergency tornado warning about the December 14, 2013 tornado?

Home (1)

Work (2)

School (3)

Other (4)

Q32 Were you registered to receive CodeRED Weather Warnings through Palm Coast PRIOR to the tornado on December 14, 2013 ?

Yes (1)

No (2)

Q5 Do you own a landline telephone?

$\square$ Yes (1)

$\square$ No (2)

Q39 Do you own a cell phone?

Yes (1)

No (2)

Q40 Do you own a TV?

Y Yes (1)

No (2)

Q41 Do you own a weather radio?

Y Yes (1)

No (2)

Q42 Do you own a desktop computer, laptop or tablet that can access the Internet?

O Yes (1)

No (2) 
Q13 Did you a receive a tornado warning on a landline telephone?

Yes (14)

No (15)

Q43 Did you receive a tornado warning on a cell phone?

Yes (1)

O No (2)

Q44 Did you receive a tornado warning through the TV?

$\bigcirc$ Yes (1)

No (2)

Q45 Did you receive a tornado warning through a desktop computer, laptop or tablet?

Yes (1)

No (2)

Q46 Did you receive a tornado warning through an outdoor warning or storm siren?

O Yes (1)

No (2)

Q47 Did you receive a tornado warning from a neighbor, friend or family member?

$\begin{array}{ll}\bigcirc & \text { Yes (1) } \\ \bigcirc & \text { No (2) }\end{array}$

Q16 What immediate action did you take after receiving the emergency tornado warning?

Went to a safe place inside (1)

Went to a safe place outside (2)

$\square$ Took no action (5)

Q38 Would you describe the area where you live as rural or suburban?

O Rural (1)

Suburban (2) 
Q1 What age group are you in?

O $18-24(1)$

O $25-34(2)$

O $35-44(3)$

O 45-54 (4)

Older than $54(5)$

Q21 Select the highest level of education you have completed.

Some high school (1)

GED/high school diploma (2)

O Associates degree (3)

Bachelor's degree (4)

O Masters degree (5)

O Ph.D. (6)

Q22 Please select your yearly individual income.

Less than $\$ 15,000$ (1)

O $\$ 15,000-\$ 34,999$ (2)

O $\$ 35,000-\$ 54,999(3)$

O $\$ 55,000$ - $\$ 74,999$ (6)

O Higher than $\$ 75,000(7)$

Q23 Please select your yearly total household income.

Less than $\$ 30,000$ (1)

O $\$ 30,00$ - $\$ 49,999$ (2)

O $\$ 50,000-\$ 74,999(3)$

O $\$ 75,000$ - $\$ 94,999$ (4)

O Higher than $\$ 95,000(5)$

Q24 How would you describe your race or ethnicity?

White or Caucasian (1)

O Hispanic or Latino(a) (2)

O Black or African American (3)

O Asian American, Native Hawaiian, or Pacific Islander (4)

American Indian or Native American (5)

O Multi-racial/Multi-ethnic (6)

O Other (7) 
Q26 Please select your gender.

Male (1)

O Female (2)

Q31 Please select your marital status.

O Single (1)

Married or domestic partnership (2)

O Widowed (3)

O Divorced (4)

O Separated (5)

Q29 Thank you for your participation in the survey. If you are not currently enrolled to receive future severe weather warnings in Palm Coast, please click here to sign up. Alerts are free and enrollment takes only a minute. The following questions will supplement the findings of the survey but are not required for you to answer. If you do not want to answer any additional questions, simply close out of the survey window. However, the City of Palm Coast encourages you to answer these supplemental questions honestly and accurately so future tornado warnings may be more effective in your community.

Your responses will be shared with the City of Palm Coast for their consideration of emergency tornado notification preparedness in your community. If you have questions regarding this survey, please contact Stephanie Meyers, University of Missouri-Columbia graduate student, at seghx4@missouri.edu.

Q17 Did you feel you had adequate warning about the tornado?
Y Yes (1)
No (2)

Q18 In what way could your warning have been more useful?

Q19 For future emergency tornado alerts from your public safety organization, please rate each of the media below to indicate how important each of these devices is to you personally, 6 being the most important and 1 being the least important.

Landline telephone (1)

Mobile device (2)

Television (3)

Weather radio (4)

Desktop, laptop or tablet with Internet connection (5)

Outdoor warning/storm siren (6) 
Q20 Please tell us how much you agree or disagree with each of these statements, with 5 indicating you strongly agree and 1 meaning you strongly disagree:

I feel confident that if there is another tornado warning in the future, I will receive it in time to be safe. (1)

I feel confident that if I am at HOME when a future tornado warning occurs, I will receive it in time to be safe. (2)

I feel confident that if I am at WORK when a future tornado warning occurs, I will receive it in time to be safe. (3) 


\section{Appendix $\mathbf{H}$}

Q28 Research Study Title: The Effects of New Media for Emergency Tornado Notification on the Digital Divide Principal Investigator: Stephanie Meyers, Graduate Student, University of Missouri-Columbia Contact information: seghx4@mail.missouri.edu

Participation in this research project is completely voluntary. You have the right to say no. You may change your mind at any time and withdraw. You may choose not to answer specific questions or to stop participating at any time.

The purpose of this research is to determine the size and impact, if any, of the digital divide when it comes to receiving emergency tornado messages. Technology continues to present new, advanced methods of communicating but it has also created a modern day digital divide - separating audiences based on their ability to receive warnings because of socioeconomic or demographic differences. Douglas County would like to thank you for your interest in this survey regarding the EF-3 tornado that affected the county on November 17, 2013. Your participation in this survey shows your commitment to helping save lives and being a good citizen in Douglas County.

The University of Missouri-Columbia, in conjunction with Emergency Communications Network, the providers of the CodeRED emergency notification system, would like to understand how residents of Douglas County are notified of tornado threats. You are encouraged to respond to this survey ONLY if you are 18 or older and lived within Douglas County limits in November 2013 to ensure the findings of the research are accurate. If you know of anyone else who lives in Douglas County who may have also been impacted by the recent tornado, please also encourage them to participate in the survey.

Q33 Were you in or near Douglas County on November 17, 2013 when the tornado hit?

$\bigcirc$ Yes (1)

No (2)

Q36 Before the tornado hit, did you know there was a possibility of tornadoes in Douglas County that day?

Yes (1)

No (2) 
Q14 Where were you when you received an emergency tornado warning about the November 17, 2013 tornado?

Home (1)

O Work (2)

School (3)

Other (4)

Q32 Were you registered to receive CodeRED Weather Warnings through Douglas County PRIOR to the tornado on November 17, 2013?

Yes (1)

No (2)

Q5 Do you own a landline telephone?

$\square$ Yes (1)

$\square$ No (2)

Q39 Do you own a cell phone?

O Yes (1)

O No (2)

Q40 Do you own a TV?

$\bigcirc$ Yes (1)

No (2)

Q41 Do you own a weather radio?

$\bigcirc$ Yes (1)

No (2)

Q42 Do you own a desktop computer, laptop or tablet that can access the Internet?

Y Yes (1)

No (2) 
Q13 Did you a receive a tornado warning on a landline telephone?

Yes (14)

No (15)

Q43 Did you receive a tornado warning on a cell phone?

Yes (1)

No (2)

Q44 Did you receive a tornado warning through the TV?

Yes (1)

No (2)

Q45 Did you receive a tornado warning through a desktop computer, laptop or tablet?

Y Yes (1)

No (2)

Q46 Did you receive a tornado warning through an outdoor warning or storm siren?

Yes (1)

No (2)

Q47 Did you receive a tornado warning from a neighbor, friend or family member?

Y Yes (1)

No (2)

Q16 What immediate action did you take after receiving the emergency tornado warning?

$\square$ Went to a safe place inside (1)

Went to a safe place outside (2)

$\square$ Took no action (5) 
Q38 Would you describe the area where you live as rural or suburban?

Rural (1)

Suburban (2)

Q1 What age group are you in?

O $18-24(1)$

O $25-34(2)$

O $35-44$ (3)

O 45-54 (4)

O Older than 54 (5)

Q21 Select the highest level of education you have completed.

Some high school (1)

O GED/high school diploma (2)

O Associates degree (3)

Bachelor's degree (4)

Masters degree (5)

O Ph.D. (6)

Q22 Please select your yearly individual income.

Less than $\$ 15,000$ (1)

O $\$ 15,000-\$ 34,999$ (2)

O $\$ 35,000-\$ 54,999$ (3)

O $\$ 55,000$ - $\$ 74,999$ (6)

Higher than $\$ 75,000(7)$

Q23 Please select your yearly total household income.

Less than $\$ 30,000$ (1)

O $\$ 30,00$ - $\$ 49,999$ (2)

O $\$ 50,000$ - $\$ 74,999$ (3)

O $\$ 75,000$ - $\$ 94,999$ (4)

Higher than $\$ 95,000$ (5) 
Q24 How would you describe your race or ethnicity?

O White or Caucasian (1)

O Hispanic or Latino(a) (2)

O Black or African American (3)

O Asian American, Native Hawaiian, or Pacific Islander (4)

O American Indian or Native American (5)

O Multi-racial/Multi-ethnic (6)

Other (7)

Q26 Please select your gender.

O Male (1)

O Female (2)

Q31 Please select your marital status.

O Single (1)

O Married or domestic partnership (2)

O Widowed (3)

O Divorced (4)

O Separated (5) 
Q29 Thank you for your participation in the survey. If you are not currently enrolled to receive future severe weather warnings in Douglas County, please click here to sign up. The following questions will supplement the findings of the survey but are not required for you to answer. If you do not want to answer any additional questions, simply close out of the survey window. However, Douglas County encourages you to answer these supplemental questions honestly and accurately so future tornado warnings may be more effective in your community.

Your responses will be shared with Douglas County Emergency Management and associated public safety officials for their consideration of emergency tornado notification preparedness in your community. If you have questions regarding this survey, please contact Stephanie Meyers, University of Missouri-Columbia graduate student, at seghx4@missouri.edu.

Q17 Did you feel you had adequate warning about the tornado?

Yes (1)

No (2)

Q18 In what way could your warning have been more useful?

Q19 For future emergency tornado alerts from your public safety organization, please rate each of the media below to indicate how important each of these devices is to you personally, 6 being the most important and 1 being the least important.

Landline telephone (1)

Mobile device (2)

Television (3)

Weather radio (4)

Desktop, laptop or tablet with Internet connection (5)

Outdoor warning/storm siren (6)

Q20 Please tell us how much you agree or disagree with each of these statements, with 5 indicating you strongly agree and 1 meaning you strongly disagree:

I feel confident that if there is another tornado warning in the future, I will

receive it in time to be safe. (1)

I feel confident that if I am at HOME when a future tornado warning occurs, I will receive it in time to be safe. (2)

I feel confident that if I am at WORK when a future tornado warning occurs, I will receive it in time to be safe. (3) 